\title{
Review
}

\section{PV - Battery Energy Storage Progress in Brazil: A Review}

\author{
Juliana D. A. Mariano ${ }^{1,2 *}$, Patrícia M. B. de Freitas ${ }^{2}$, Lúcio de Medeiros ${ }^{2}$, Pedro A. B. Block², Victor B. Riboldi ${ }^{3}$, Ji \\ $\mathrm{Tuo}^{3}$ and Jair Urbanetz $\mathrm{Jr}^{1}$ \\ 1 Department of Civil and Electrical Engineering, Federal University of Technology - Paraná, 80230-901, Curi- \\ tiba, Brazil, urbanetz@utfpr.edu.br (J.U.J.) \\ 2 Power System, Lactec, 81531-980, Curitiba, Brazil; patricia.freitas@lactec.org.br (P.M.B.F); \\ lucio.medeiros@lactec.org.br (L.M.); pedro.block@lactec.org.br (P.A.B.B.) \\ 3 CPFL Energia, 13202-251, Campinas, Brazil; riboldi@cpfl.com.br (V.B.R.); jituo@cpfl.com.br (J.T.) \\ * Correspondence: juliana.mariano@lactec.org.br (J.D.A.M.)
}

\begin{abstract}
Integration of battery energy storage in photovoltaic (PV) systems can reduce the electricity costs and provide desirable flexibility and reliability to these systems decreasing renewable energy fluctuations. This paper presents a review of the PV-battery application in Brazil, highlighting the challenges and prospects based on the state-of-art. A PV-battery systems description is presented in this work, as well as the most applied battery technology and its comparison. The paper also describes the set of applications such as voltage and frequency regulation, renewable energy integration, power quality, etc. In the Brazilian scenario, there are applications of PV-battery systems, most of them part of research and development projects (R\&D's), and some real cases are shown, including its goals, applied equipment, operation modes, strategies, and perspectives. Additionally, this work evaluates the Brazilian scenario regarding the energy storage systems implementation challenges, such as regulatory barriers, business models, and opportunities for R\&D in the energy market. In conclusion, it is need develop proper regulatory models to expand PV-battery systems and make them visible to the agents in the electricity sector.
\end{abstract}

Keywords: Energy storage system, photovoltaic systems, PV-battery, regulatory issues, energy management.

\section{Introduction}

The constant demand for energy in urban populations, specifically developing countries such as Brazil, puts pressure as renewable energy needs to be distributed to achieve a more sustainable transition. PV-grid-tie systems are playing a vital role in this transition to the electricity sector due to its benefits regarding the environment and reduced emissions [1]. In Brazil, there was a significant growth in distributed PV power plants since the National Electric Energy Agency (ANEEL) established regulatory standards in 2012. According to ANEEL [2], by early-May 2021 around 597,467 PV-grid-tie systems were implemented in Brazil, approximately $5.5 \mathrm{GWp}$ rated power. It is expected that around 1.2 million consumer units will produce their own energy by 2024 [3]. Table 1 shows this distributed generation (DG) evolution in Brazil regarding to systems installations.

Table 1. The annual number of DG connection in Brazil [2].

\begin{tabular}{cccccccccc}
\hline $\mathbf{2 0 1 2}$ & $\mathbf{2 0 1 3}$ & $\mathbf{2 0 1 4}$ & $\mathbf{2 0 1 5}$ & $\mathbf{2 0 1 6}$ & $\mathbf{2 0 1 7}$ & $\mathbf{2 0 1 8}$ & $\mathbf{2 0 1 9}$ & $\mathbf{2 0 2 0}$ & $\mathbf{2 0 2 1}^{*}$ \\
\hline 6 & 52 & 296 & 1.433 & 6.710 & 13.937 & 35.743 & 122.594 & 207.236 & 86.087 \\
\hline
\end{tabular}

* This number reflect the DG installations till early May 2021.

From an environmental standpoint, photovoltaic systems can reduce carbon footprint due to low building emissions. Besides, it can serve as a political and marketing tool for green buildings [4]. This concept is considered more sustainable ascribable to the use 
of more socio-environmental processes which offer homeowner savings [5]. PV systems are designed in a simple way for low maintenance [6]. A benefit is that they serve as standalone systems, which allows the conversion of output energy from microwatts to megawatts [7-10]. Therefore, they serve multi-purpose functions as they are used to be a power source, water pump, in solar home systems, communications, satellite, and space vehicles, reverse osmosis plants, and power plants [3, 11-12].

Despite the growth in these systems, there are technical constraints due to the intermittence and passivity [13]. As a result, PV systems present fluctuations inherent to renewable energy. These fluctuations can happen at any time within seconds to minutes requiring the assembling of an auxiliary systems for energy management purposes [14]. Furthermore, the cost difference at peak times, and the power quality provided to the power grid, also offer challenges for the PV systems [15]. Thus, energy storage technologies are key elements and can assist PV systems in providing energy through DG systems towards a sustainable future [16].

Energy storage system is also a solution in the literature to potentially remove faults [17-21]. These problems are related to energy penetration levels and may provide desirable flexibility and reliability to PV systems [22]. In this sense, PV-energy storage systems promote power management, i.e., load levelling or peak demand reduction, for power bridges and quality improvements $[23,24]$. Therefore, these systems enable on-site power flow management, so that power storage can occur during periods when demand costs are low to be used during peak periods [25]. As a result, they can reduce the costs with the demand for electricity and improve the quality of the electric network [26].

The new model for the Brazilian electricity sector, defined on July 30th 2004 through the Decree $n^{0}$ 5163, aiming to guarantee electricity supply security, offer low tariffs and bring funds and incentives [27]. Since then, the regulation for electricity commercialization was established in two dynamic environments: Regulated Contracting and Free Contracting [27]. In the first environment, there is the participation of generation, distribution, and trading agents; and the electricity purchase contracts are only made through auctions. Thus, the Electric Energy Trading Chamber (CCEE) is responsible for auction promotion and ANEEL by the regulatory issues, where the tariffs must be fair assuring energy supply to consumers. On the other hand, generators, distributors, traders, free and special consumers take place in the Free Contracting environment; in this case, the electricity market occurs through the freely negotiated form of bilateral contracts, following specific rules and procedures [27].

To foster the expansion of the renewable energy market, ANEEL approved several R\&D proposals from the 021/2016 R\&D Strategic Call named "Technical and Commercial Arrangements for the Insertion of Energy Storage Systems in the Brazilian Electric Sector" [28]. The main specific objective of this strategic call was to propose technical and commercial arrangements for the evaluation and insertion of energy storage systems in the Brazilian electricity sector. Thereby, the agency promotes and creates conditions to develop the technological base and the national production infrastructure in an integrated and sustainable manner [28]. There are several projects underway, and contributions are expected to assist in the development of the theme, such as regulatory aspects, technical and normative development, development of the national production chain, techno-economic evaluations, professional training, etc.

Energy storage is a technology that offers the possibility of helping with network flexibility. Eventually, due to this performance and the current incentive, there may be a greater interest in the use of technology and partnerships may arise to better explore its use since there is no clear definition in the regulation. The enabled project in this Strategic Call should provide subsidies for the improvement of the legal and regulatory framework, as already done through the subsidies TS011, which aiming grants obtention for the preparation of proposals for regulatory adjustments necessary for the insertion of storage systems in the Brazilian electricity sector. That way is possible to ensure the suitable functioning of energy storage systems technologies in the Brazilian electricity sector [28]. As a result, this paper presents a review of the technical, economic, and environmental benefits 
through the state-of-art of battery energy storage integration into the PV system installation.

\section{PV-Battery Storage System}

PV-energy storage is the process by which the energy generated is converted into electrochemical energy and stored in batteries [29]. PV-battery operating together (Figure 1) can bring a variety of benefits to consumers and the power grid because of their ability to maximize electricity self-consumption and power management [30].

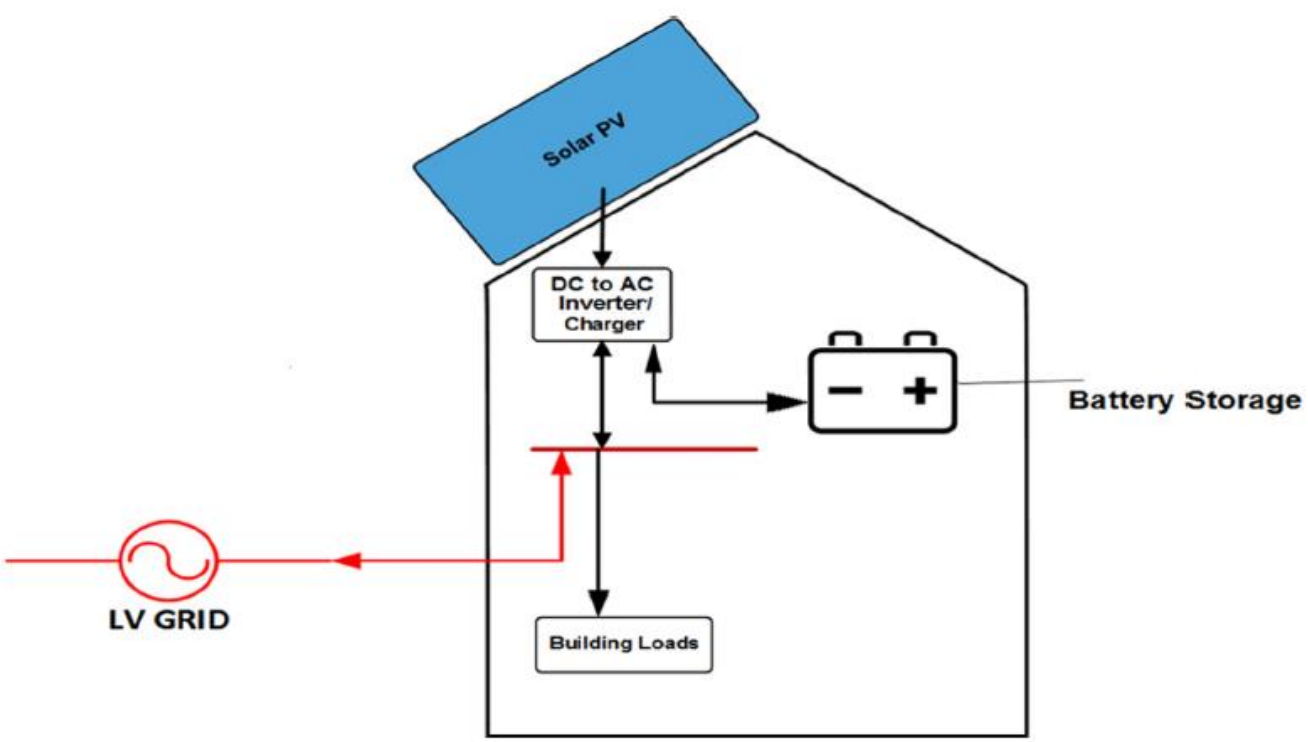

Figure 1. Residential PV-battery scheme [31].

According to Figure 1, it is possible to identify the addition of the battery and the use of the bidirectional inverter, which makes the power flows more dynamic. The battery can be charged by the PV system and the electric network [32]. Additionally, the PV-battery system also allows consumers to contribute to reduce energy demand in response to market prices, using financial incentives [33]. PV-battery systems are complex due to more variables to be considered in design and implementation. These systems will operate with the power required to meet the load profile of this consumer, which may vary from day to day or seasonally. The amount of energy produced will depend on PV panel size and daily irradiation [34]. And finally, storing energy through batteries will create supply flexibility, requiring verification of the difference between the PV power generation curve and power demand [35].

The financial benefits achieved depend largely on the exact pricing structure and policies of the place where the consumer is located [32,33]. Some power electricity companies introduced the Time of Use (TOU) rates and peak demand charges for their customers due to the increased implementation of smart meters, net metering policies and electric vehicles penetration [36,37]. Since batteries store direct current (DC) power and most household equipment requires alternate current (AC) power, an inverter is required. Besides serving this type of application, the inverter/charger or bidirectional inverter can meet other applications such as electric and hybrid vehicles, uninterruptible power systems (UPS), etc $[38,39]$. In addition, bidirectional inverters are used in hybrid systems (more than one renewable power source), to increase the power supply capabilities [40]. Regarding its operation, this device is more complex than the grid-tie PV inverter controlling the entire system including load controllers and their connection to the power grid $[41,42]$.

The bidirectional inverters must ensure safe operation and are regulated by national and international standards. The equipment shall comply with operating specifications 
regarding electromagnetism emission, harmonic current, electromagnetic immunity, and electrical safety [43]. Another important factor to consider is battery compatibility since there is a wide range of technologies available [44]. Regarding the batteries, the main classes of batteries are primary and secondary. Primary batteries cannot be recharged and therefore are not applicable in PV systems, such as carbon-zinc and lithium batteries used in consumer electronics. Secondary batteries can therefore be recharged and therefore used in PV systems [45, 46]. The most common battery types applied in these systems are lead-acid, lithium ion, and flow batteries that are applied in large-scale PV systems [47].

\subsection{Lead-acid batteries}

Lead-acid batteries are the oldest and most widely used rechargeable electrochemical devices among energy storage technologies [48]. In 1859, they were invented mostly for domestic use and a variety of commercial applications as motor starters, among other applications [29]. This type of battery consists of a lead sponge metal anode, a lead dioxide cathode, and a sulfuric acid solution electrolyte [49]. Besides the simplicity in the manufacturing process, the technology is relatively low cost compared to other batteries, a good life cycle under controlled conditions, and fast electrochemical reaction kinetics [50]. However, it also has some disadvantages related to its operation, such as performance impairment at extreme temperatures affecting its lifetime [51]. In addition, there is a need for periodic water maintenance, low energy density, and the presence of heavy metals harmful to the environment makes this technology unsuitable for certain applications [50].

Mahlia et al. [49] highlight some technological advances achieved by this technology with the development of lead-acid ultra-battery. This development is a new long-life hybrid device that can operate in a continuous Partial State of Charge (PSoC) [50]. The device is efficient and does not require charge maintenance cycles, optimum stability with longevity to charge/discharge operation, is faster, and with a deep charge range. Its loading/unloading is approximately 50 per cent longer than traditional lead-acid, and its life cycle is three times longer [52].

\subsection{Lithium-ion batteries}

Lithium-ion batteries are modern technologies less than 40 years old and recognized for their wide application in the electronics and transportation industry, the operation of plug-in electric vehicles, and the electric power system [38, 53]. Most commercial lithiumion cells consist of a negative electrode based on a layered oxide electrode and an organic solvent-based salt and lithium mixture solution electrolyte [51]. The electrolyte conducts the ionic component of the chemical reaction between the anode and cathode, forcing the electronic component to cross the external circuit [54].

The advantages of contemporary lithium-ion batteries are the ability to last over 10000 full discharge cycles, fast charge/discharge [55], and their high energy density of energy of $200 \mathrm{Wh} / \mathrm{kg}$ [56]. Nevertheless, the high initial cost is a limiting factor to the extensive application of lithium-ion batteries in power grid, as well as their production cost, as they require special packaging and internal overload protection circuits [50, 57].

The lithium-ion battery family features a wide range of commercial materials such as cobalt lithium oxide (LCO), nickel and lithium cobalt manganese oxide (NCM), lithium nickel oxide, and cobalt aluminum (NCA), lithium iron phosphate (LFP), lithium titanium oxide (LTO) [58]. Despite that, research must continue with advances in new electrode materials to exceed cost, power, energy density, life, and safety limits [50, 58].

\subsection{Flow batteries}

Flow batteries, also known as redox flow batteries, are relatively mature systems. This type of battery includes all vanadium redox flow, Zinc-cerium (Zn-Ce) hybrid redox flow, iron-chrome flow, and zinc / flow bromine [57].

The first studies on redox flow batteries were proposed in 1970, and among the most prominent groups is the pioneering University of New South Wales. The research team 
has met the performance requirements for large-scale, long life cycle energy storage applications of about 80 per cent in large facilities [59].

In a flow battery, the energy is charged/discharged through a chemical (reversible) reaction between the two liquid electrolytes [51]. Unlike conventional batteries, liquid electrolytes are contained in separate tanks. During operation, these electrolytes are pumped through the electrochemical reactor, where a local chemical redox reaction and electricity is produced [50]. The constructive complexity of these systems and their intricates are the need for pumps, sensors, power management, and secondary containment [60]. Additionally, they have low energy density making them unsuitable and not feasible for small-scale energy storage applications [61].

Flow battery industrialization still faces restrictions regarding critical materials [62]. Advances should occur on electrodes with low resistance, as electrochemical performance, as well as system design, shall be optimized [50]. For these reasons, large-scale production and marketing are limited due to the high cost of manufacturing [57]. Table 1 presents a comparison of battery technology's properties in terms of lifetime, price, maturity, discharge time, power, advantages, and disadvantages, as well as the appropriate applications for each technology.

Table 2. Battery technology comparisons

\begin{tabular}{llll}
\hline Technology & Lead acid & Lithium ion & Redox flow \\
\hline Rated Power (MW) & $<36$ & $<102$ & $<28$ \\
Energy density (Wh/kg) & $<50$ & $<200$ & $<30$ \\
Charge length (h) & $<8$ & $<6$ & $<10$ \\
Efficiency (\%) & $75-85$ & $90-94$ & $70-85$ \\
Lifetime (y) & $500-1200$ & $1000-10000$ & $12000-18000$ \\
Cost (USD/kWh) & $300-600$ & $1200-4000$ & $600-1200$ \\
& & & \\
Advantages & Low cost & High efficiency & High discharge depth \\
& Recyclable content & High energy density & High roundtrip \\
& & Long lifecycle & Faster charge/discharge \\
& & & \\
Disadvantages & Low energy density & High manufacture costs & Low efficiency \\
& Low discharge depth & Overheating & Low energy density \\
& High footprint & Protection requirements & High areas and costs \\
& & & \\
Applications & Spinning reserve & Spinning reserve Fre- & Spinning reserve Frequency \\
& Frequency control & quency control & control Peak/load-shaving \\
& Peak/load-shaving & Peak/load-shaving & Power quality \\
& & Power quality & \\
References & {$[29,48-51]$} & {$[51,53,54-57]$} & [50, 51, 57, 59, 60, 61] \\
\hline
\end{tabular}

\section{Applications for Battery Storage Systems}

The set of solutions involving decentralized generation, supervision, and control strategies for energy management and storage helped to create the concept of smart grids. The intelligence of these systems is not just about reducing the technical constraints, but making the electric network greener, more efficient, adaptable to the customer needs, and therefore less costly [62]. These grids aggregate the use of IT (Information Technology), enabling two-way communication between the power grid (utility) and the building 
(customers), which results in sensing on both sides, making the grid "smart" as they are more efficient and resilient than the conventional power grid [63].

As a result, smart grids open the industry to new applications with far-reaching interdisciplinary impacts due to their ability to safely supply and integrate more renewable energy sources, grid-based generators, and smart buildings [62]. Thus, exceptionally reliable communication will be required to transfer a high volume of data. Therefore, communication and network technologies will play a significant role in the integration of smart buildings and power grids [64].

Several changes in the electric systems have been occurring since the emergence of the smart grids concepts, causing a restructuring in the sector and technological advances. These changes also bring about regulatory changes and can bring several inherent benefits to power generation systems through the services provided by these systems. However, energy storage is not limited to meeting long-term variations in energy production caused by short-term intermittent inherent renewable sources. These systems present important features to the electrical system and consumers. Energy storage systems may have quite different applications and capacities, and therefore have a slow or fast response [65]; some of these services as described below.

\subsection{Regulation}

Regulation involves managing energy flow with other control areas to combine scheduled flow and instantaneous fluctuations in demand. The main reason for regulation is to maintain frequency and voltage within industry-established standards [48]. In practical terms, this application is characterized by the continuous balance between the supply and demand of electricity, with regards to the frequency or load, and the regulation of active (low) and reactive powers (high) $[48,51,53,65,66]$.

Voltage regulation is a requirement in the electric power system [48]. This application involves the management of reactance, caused by grid-connected equipment that generates, transmits, or uses electricity and often has or exhibits characteristics such as inductors and capacitors in an electrical circuit [67]. Thus, these power plants (reactive energy VAR) could either be replaced by energy storage strategically placed within the grid at central locations or through the distributed approach, inserting several VAR support storage systems close to large loads [50,68].

There is also the frequency response function, which is similar to regulation, except that it responds to system needs in even shorter periods, of seconds to less than one minute, when there is a sudden loss of frequency response [51].

\subsection{Integration of renewable-power generation}

Energy storage accomplishes load smoothing caused by the intermittence of wind and PV systems [50, 69]. In this function, within minutes, there is a load ramp support to respond to a fast or randomly floating load profile $[48,60,65]$. As a result, renewable energy generation can be controlled, smoothed, and dispatchable, especially in remote places $[53,55,68,70]$. Furthermore, different modes of operation must combine to reach feasibility, such as power quality control, load management, and others discussed next $[51,71]$.

\subsection{Power quality}

Power quality mode operations provide improvements in the grid system concerning the deficiencies [69]. For instance, this application involves applying storage to protect the consumers' loads and transmission lines against events that may affect their loads, such as $[48,55,67]$ :

- Voltage variations (i.e., short term spikes or dips, long term spikes or dips) [51, 72].

- Variations in the primary frequency of $60 \mathrm{Hertz}(\mathrm{Hz})$ at which power is supplied [72].

- Low power factor (excessively out of phase voltage and current) [72]. 
- Harmonics (i.e., the presence of currents or voltages at frequencies other than the primary frequency) [51, 72].

- Service interruptions of any duration, ranging from a fraction of a second to several seconds [72].

\subsection{Back up (power reliability)}

In backup mode, in the event of a total loss of power, a storage system can effectively endurance the customer's loads [48]. This mode is applied to supply permanent systems or those temporary in off-grid operation [65]. Additionally, it can also be operated as an emergency power source to provide power to users, especially telecommunications [50].

The storage system's power capacity regarding the protected load size determines how long the storage can meet that load and be resynchronized. Thus, this mode is also a feature available as demand reduction $[48,55]$.

\subsection{Load-shifting}

Load-shifting postpones renewable energy delivery from non-peak to peak utility demand [51]. In practice, energy is purchased during periods when prices are lower and can be stored in these systems for use or sale at times when energy prices are high [48, 50, 67]. This mode of operation combined with PV generation can also store the surplus energy produced that will be used when the energy demand is higher [55, 60, 73].

\subsection{Peak-shaving}

The peak-shaving mode is a form of operation that enables the reduction of demand peaks through storage to meet a certain load or reduction of the need to buy new energy demand. With this mode of operation, the PV system will be able to discharge its energy through the batteries for a period, such as during peak hours [60, 67, 50, 73].

Besides, this mode of operation can provide backup support, and use of uninterruptible power supply (UPS) to address short- and long-term interruptions, voltage peaks, and flickers [53].

\subsection{Transportation applications}

Storage systems have impacts on electric and hybrid vehicles (EV), although not yet widely used [69]. However, as technology advances, storage may improve the integration of these vehicles into smart grids [55]. This integration will be better recognized through the flexibility of the power flow from the network to the vehicle, and vice versa [38].

Uddin et al. [69] confirm that despite the limited application, storage systems utilization may become popular in a few years. Another possible application for them is to provide peak shaving services in buildings, as this energy stored in electric and hybrid vehicles is not fully used daily. In this context, Silva et al. [74] and Silva [75] developed a prototype of a self-sufficient PV-EV that can be charged by the power grid or PV system, also capable of providing peak-shaving services.

Table 3 presents a list of countries worldwide which bring storage system with related services [76-85], according to the DOE (Department of Energy) Global Energy Storage Database [85].

Table 3. Global energy storage database list of countries and services cases versus technologies

\begin{tabular}{llccr}
\hline Country & Services cases & $\begin{array}{c}\text { Rated } \\
\text { Power } \\
(\mathrm{kW})\end{array}$ & $\begin{array}{c}\text { Duration } \\
\text { (hours) }\end{array}$ & $\begin{array}{c}\text { Technology/Re- } \\
\text { lated References }\end{array}$ \\
\hline Australia & $\begin{array}{l}\text { Voltage Regulation, Load-shifting, } \\
\text { Peak-shaving, Power Quality, Back-up, } \\
\text { Renewable Integration }\end{array}$ & 150 & 4,5 & Lead-acid [76] \\
\hline
\end{tabular}




\begin{tabular}{|c|c|c|c|c|}
\hline Cape Verde & $\begin{array}{l}\text { Renewables Capacity Firming, Renewa- } \\
\text { bles Energy Time Shift, On-Site Power }\end{array}$ & 28 & 15,42 & Lead-acid [77] \\
\hline Germany & $\begin{array}{l}\text { Black Start, Distribution upgrade, Fre- } \\
\text { quency Regulation, Load/Time-Shift- } \\
\text { ing, Reserve-Non-Spinning, Renewable } \\
\text { Integration }\end{array}$ & 200 & 4,4 & Redox flow [78] \\
\hline India & $\begin{array}{l}\text { Renewables Capacity Firming, Onsite } \\
\text { Renewable Generation Shifting, Electric } \\
\text { Supply Capacity, Microgrid Capability }\end{array}$ & 40 & N/A & Lead-acid [79] \\
\hline Italy & Electric Supply Capacity & 450 & 3,2 & Redox flow [80] \\
\hline South Korea & Resiliency, Voltage Support & 150 & 1,92 & Lead-acid [81] \\
\hline New Zealand & Time-Shift, Renewable Integration & 500 & 5 & Redox flow [82] \\
\hline Spain & $\begin{array}{l}\text { Demand Response, Electric Bill Man- } \\
\text { agement, Electric Bill Management with } \\
\text { Renewables, Microgrid Capability }\end{array}$ & 40 & 2,4 & Lead-acid [83] \\
\hline United Kingdom & $\begin{array}{l}\text { Onsite Renewable Generation Shifting, } \\
\text { Electric Supply Capacity, Frequency } \\
\text { Regulation, Voltage Support, Load Fol- } \\
\text { lowing (Tertiary Balancing) }\end{array}$ & 60 & 3,67 & Lead-acid [84] \\
\hline $\begin{array}{l}\text { United States of } \\
\text { America }\end{array}$ & $\begin{array}{l}\text { Grid-Connected Commercial (Reliabil- } \\
\text { ity, Ramp; Quality), Grid-Connected } \\
\text { Residential (Reliability), Renewables } \\
\text { Capacity Firming, Resiliency }\end{array}$ & 450000 & N/A & Lithium-ion [85] \\
\hline
\end{tabular}

\section{Current Status and Some Real PV-Battery Projects}

This section presents some Brazilian cases in which energy storage systems have been applied with the PV generation, considering their modes of operation, storage technology types, and results achieved in these systems so far.

\subsection{University of São Paulo}

In the Brazilian scenario, there are few applications in photovoltaic systems that include electrochemical storage, which is being restricted to universities and research centers. The applied case is the photovoltaic system installed at the University of São Paulo 
(USP), which has several bidirectional inverters installed in several single-phase and three-phase mini-grids used for tests and research by the Energy and Environment Institute (IEE-USP).

The case brought to this article is the $3 \mathrm{kWp}$ photovoltaic system in a three-phase mini grid installed at USP for AC coupling. According to the image labelled [86], the photovoltaic system is installed on a roof of a parking lot (Figure 2a), while the battery bank consists of 24 elements, each with lead-sulfuric acid inside (Figure 2b). The electrical characteristics of this bank and $500 \mathrm{Ah}$ and $2 \mathrm{~V}$ for each element, and the bidirectional inverter operates with a voltage of $48 \mathrm{~V}$.

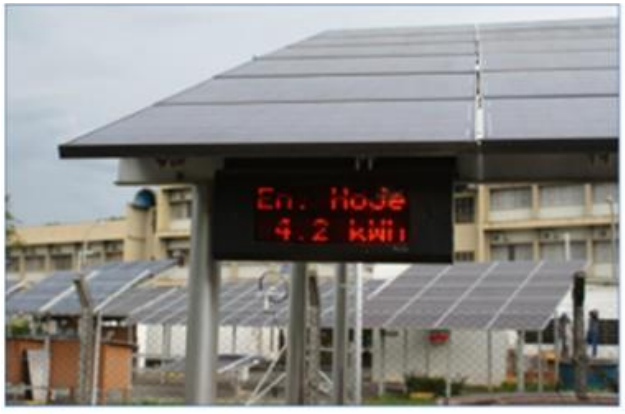

a

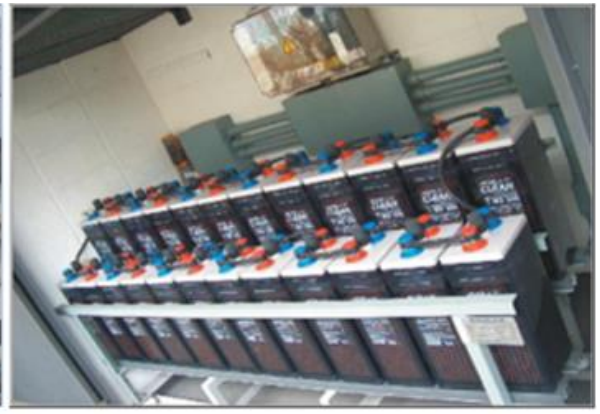

b

Figure 2. USP's PV-Battery system [86].

According to [86], the bidirectional photovoltaic system operates dynamically so that in times of high productivity and low demand for electricity at USP, the inverter extracts the power from the AC bus by charging the batteries. When the opposite occurs, the bidirectional inverter works by extracting energy from the batteries supplying the AC bus.

It is important to highlight that the systems installed at USP include mini-grids with bidirectional inverters, which represents the state of the art of this application, as well as the systems installed by the Study and Development of Energy Alternatives Group (GEDAE) from the Federal University of Pará (UFPA), among the experiences experienced by the European community described in the Large-Scale Integration of the MicroGeneration to the Low Voltage Grids project [86].

\subsection{Federal University of Santa Catarina}

The Federal University of Santa Catarina (UFSC) has a Strategic Research Group on Solar Energy for develop research and development on energy storage applied to smart grids. The group has under development an R\&D project entitled "An investment; Multiple Functions" in partnership with the company ENGIE (Tractebel) and Dresser-Rand (SIEMENS).

The UFSC project has four objectives which focus on the application of energy storage systems in large, centralized plants (Cidade Azul Solar Plant - Figure 3a), mediumsized decentralized plants (UFSC and ENGIE Customers - Figure 3b), as shown in Figure 3, small, decentralized plants (ENGIE Customers - Figure 3c), and a quick recharge station for electric vehicles and buses. 


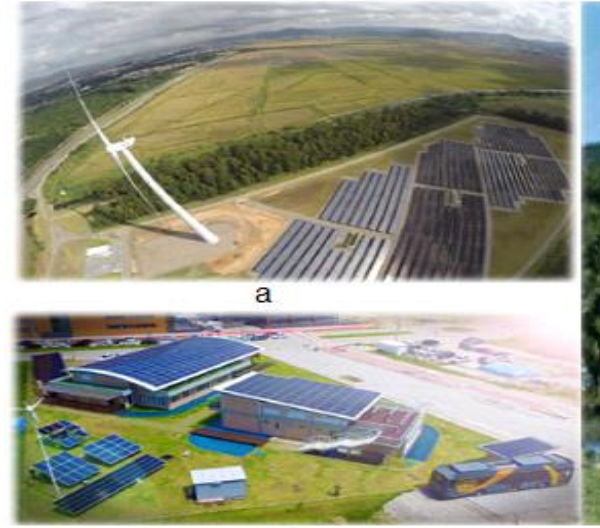

b

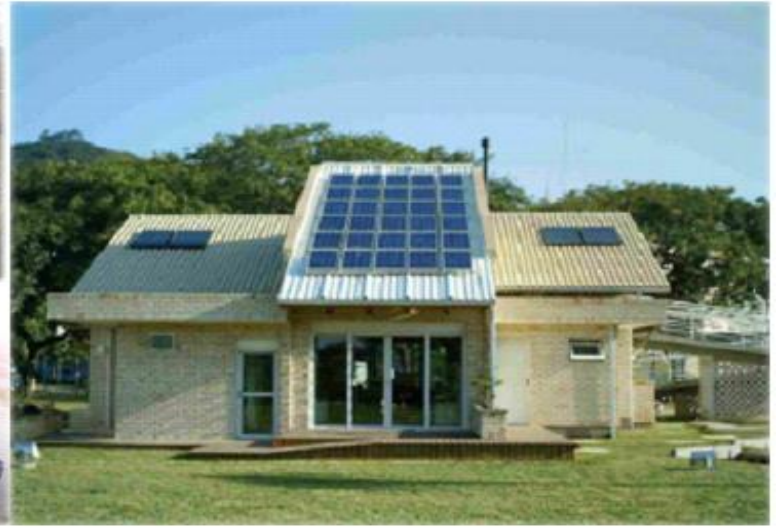

C

Figure 3. UFSC energy storage application locations [87].

According to the image labelled [87] in the large centralized applications, the proposal is to integrate a $1 \mathrm{MWh} / 1 \mathrm{MW}$ lithium-ion battery plus $4 \mathrm{MWh} / 1 \mathrm{MW}$ zinc-air next to the Cidade Azul Solar Plant (Figure 3a) which is a hybrid solar plant / wind power.

The strategy is to use existing equipment in the international market, such as storage containers, Siemens's monitoring software, protection ready, and security systems. The second objective is to integrate $100 \mathrm{kWh}$ of lithium-ion batteries plus $100 \mathrm{kWh}$ of redox flow vanadium batteries in urban buildings and 180 to $400 \mathrm{kWh}$ of lithium-ion in an ENGIE client. It is important to highlight the vanadium battery the use of 5,000 electrolytes for $100 \mathrm{kWh}$ [87].

The third objective is to integrate up to five single-family urban buildings with 10 $\mathrm{kWh}$ of lithium-ion batteries, applying the same strategy along with equipment existing in the international market, such as Sonnen inverters. After all, the fourth objective is to develop a recharging station for CC-CC (battery-battery) electric vehicles and test its applications in small (Renault's Twzy) and medium-sized (bus) electric vehicles [87].

\subsection{Federal University of Pará}

The Group of Studies and the Development of Energy Alternatives (GEDAE) of the Federal University of Pará (UFPA), presents several hybrid systems installed in its laboratories. These smart grids involve several generation blocks inserted in the electrical environment. This group performs monitoring, hybrid systems analysis, and PV and wind data from a mini-grid. The PV system has $3 \mathrm{kWp}$ of rated power and is connected to the bidirectional single-phase inverters SMA brand (Figure 4a). Additionally, there are Outback load controllers and a management / monitoring system called Mate 3. As for the battery bank, they are based on 48V / 490Ah VRLA lead-acid technology (Figure 4b), using the same strategy as USP, due to partnerships between these institutions [88]. These devices are shown in Figure 4.

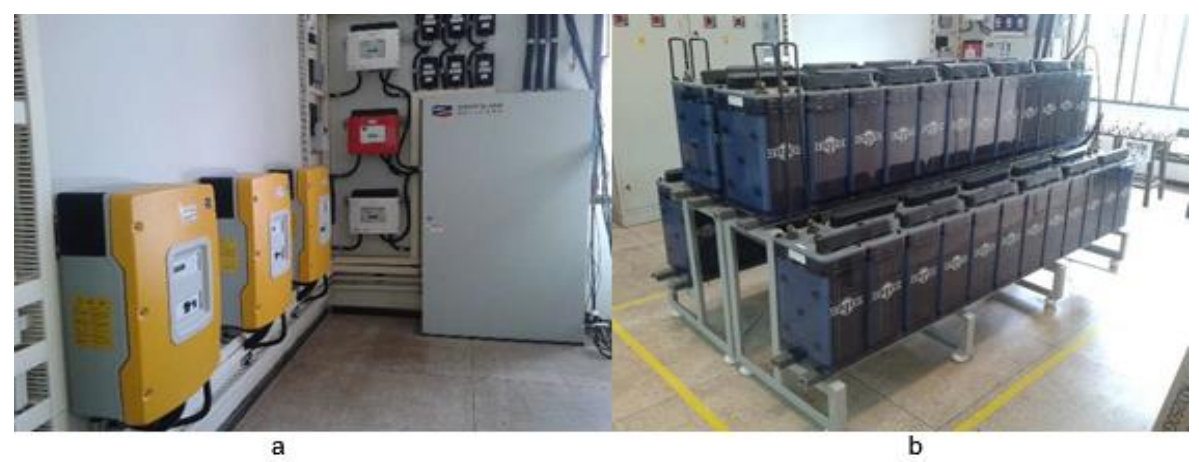

Figure 4. UFPA's bidirectional inverters (a) and battery bank (b) [88]. 
Similar to what happens at USP laboratories, the bidirectional system can charge the batteries both by the PV system and by the grid. This is dependent on the energy requirement of the network, being able to reduce energy peaks, displace loads, feed a load regardless of network, or regulate electrical network parameters, which includes solar, wind, and generator set technologies. The group's challenge was to make this grid interact to take advantage of these systems [88].

\subsection{Lactec Institute}

The Lactec Institutes presented a PV plant that was installed in 2014, which was part of an $R \& D$ project related to Smart Grids in partnership with the electricity company Light SESA. This system was designed to operate in several functions, including powering an electric car, as shown in Figure 5. To meet these specifications, $132 \mathrm{PV}$ modules of 230Wp each were installed - W Solar brand, a total installed power of 30, 36kWp (Figure 5a).

For the conversion of the energy generated by the DC system of the PV cells, nine single-phase $3600 \mathrm{~W}$ inverters (Figure $5 \mathrm{~b}$ ) from the Outback Power Technologies brand were installed which formed a three-phase network that connected it to the electrical grid of the Copel electricity company. According to the manufacturer's catalog, this equipment consists of a sine wave inverter from DC to AC, a battery charger, and an AC transfer switch (switch), which makes it possible to disconnect the loads from the public network and supply them from the inverter in the event of an outage using a battery bank [89].

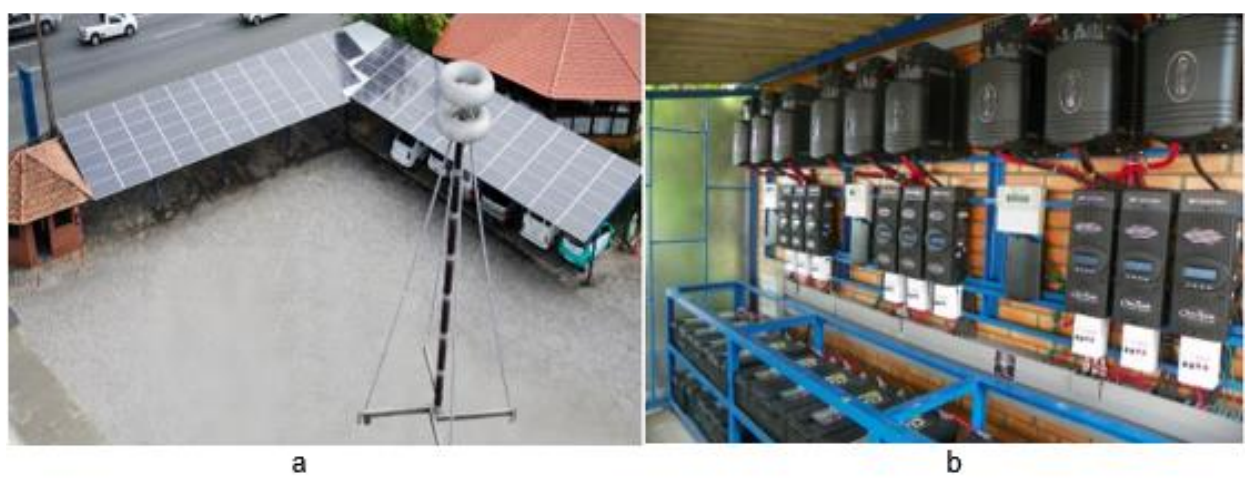

Figure 5. Lactec's PV panel (a) and battery bank-inverters (b) [89].

In this way, the equipment is capable of servicing loads when there is no power supply (energy backup), from the application of a battery bank to store the energy produced by the PV system. In addition, the system operates in a connected way to the electrical grid (on-grid), being able to inject the surplus in the electrical grid when the stored energy exceeds the capacity of the battery bank or charge the batteries through the electrical grid [90].

To expand studies in the area of energy storage systems, optimum control of these systems through the development of algorithms, technical and economic feasibility, and market regulation studies in this sector, Lactec forecasts the implementation of a microgrid in their laboratories. With this, there will be the installation of a hybrid storage system which will include batteries and supercapacitors, as well as bidirectional inverters and simulators in real-time which serves as a support for future research and development that the institute will perform [89-91].

\section{.5. Federal University of Technology - Paraná}

Aiming at better utilization of the energy generated by UTFPR's PV systems, the Solar Energy Laboratory (Labens) approved an R\&D called "Methodology for Analysis, Monitoring and Management of GD by Incentive Sources" in partnership with Copel utility, with several objectives, among them to perform the energy management through the application of batteries with the PV generation. To achieve this goal, a project for the installation of a third grid-connected PV system with a bidirectional inverter and batteries 
at the UTFPR Neoville headquarters was developed to demonstrate various functionalities (Figure 6) [92].

The proposed system aims to perform various operations, such as reducing fluctuations in a photovoltaic generation, peak-shaving reduction, power backup, load shifting, islanded mode operation independent of the power grid regulation of voltage levels, frequency regulation, and reactive control of feeders [92].

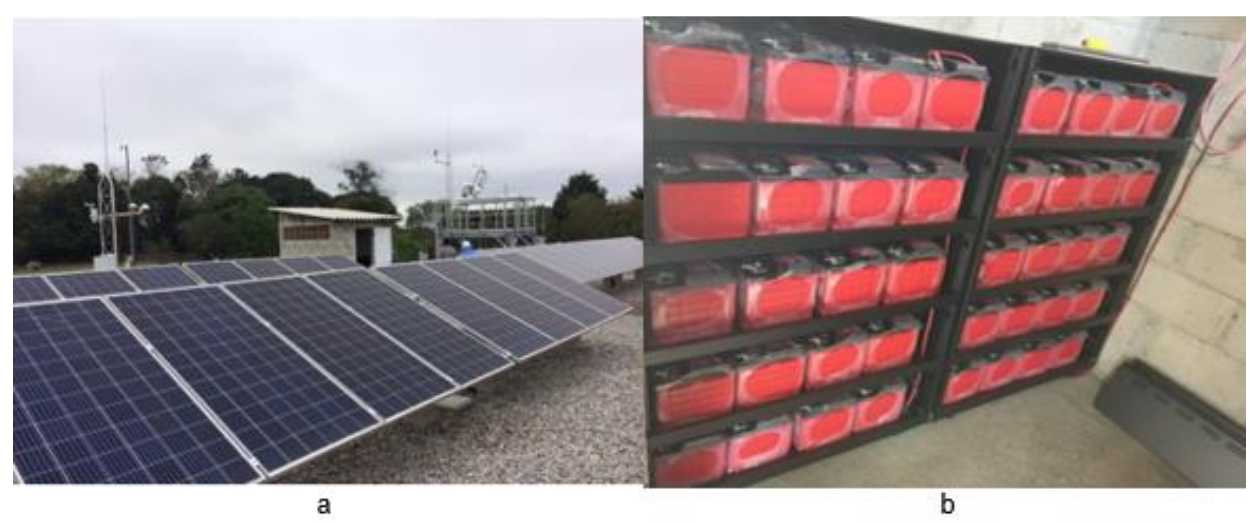

Figure 6. UTFPR's PV array (a) and battery bank (b) [92].

To meet the specifications of this project, the system consists of a $10.88 \mathrm{kWp}$ of PVpanel (Figure 6a), 2 bidirectional single-phase inverters of 5,4 kW, and 2 series battery racks consisting of 32 batteries for each inverter, 58Ah stationary type and $12 \mathrm{~V}$ (Figure $6 \mathrm{~b})$. Regarding the mode of operation, it was a range of 3 hours and a discharge depth of 20 per cent in the battery bank [92].

Making a projection to the Brazilian scenario, the PV-battery integration could have better use in the buildings through PV system charge/recharge. This assumption could be applied in commercial buildings, where their energy demand profile is generally in the daytime. In addition, these consumers have greater availability for the application of these systems [92].

Thus, the expectation of the system's annual electricity generation is 13.2MWh with the possibility of a scheduled injection of $56.7 \mathrm{kWh}$ energy into the grid during peak hours which is between 18:00 - 21:00 to meet a portion of demand for electricity from the university [93].

The perspectives of this university pilot project aim to demonstrate the feasibility of the PV-Battery system enabling the greater use of the PV system. Therefore, the strategy can increase the autonomy of the commercial consumers, making its operation more flexible [93].

\section{PV-Battery Potential and Perspectives}

In the Brazilian territory, there is a great solar availability, which can be applied to generate electricity through PV systems. Figure 7 highlights the solar map showing the irradiation present the yield maximum annual energy (measured in $\mathrm{kWh}$ of electricity generated per year for each $\mathrm{kWp}$ of power installed photovoltaic). According to [3] is important to highlight that in the least sunny location in Brazil, it is possible to generate more solar electricity than in the sunniest spot in Germany with $900 \mathrm{kWh} / \mathrm{kWp}$.year, for example. Therefore, it is possible to apply the PV systems on large scale as well as the DG, integrated into buildings and their roofs [3]. 


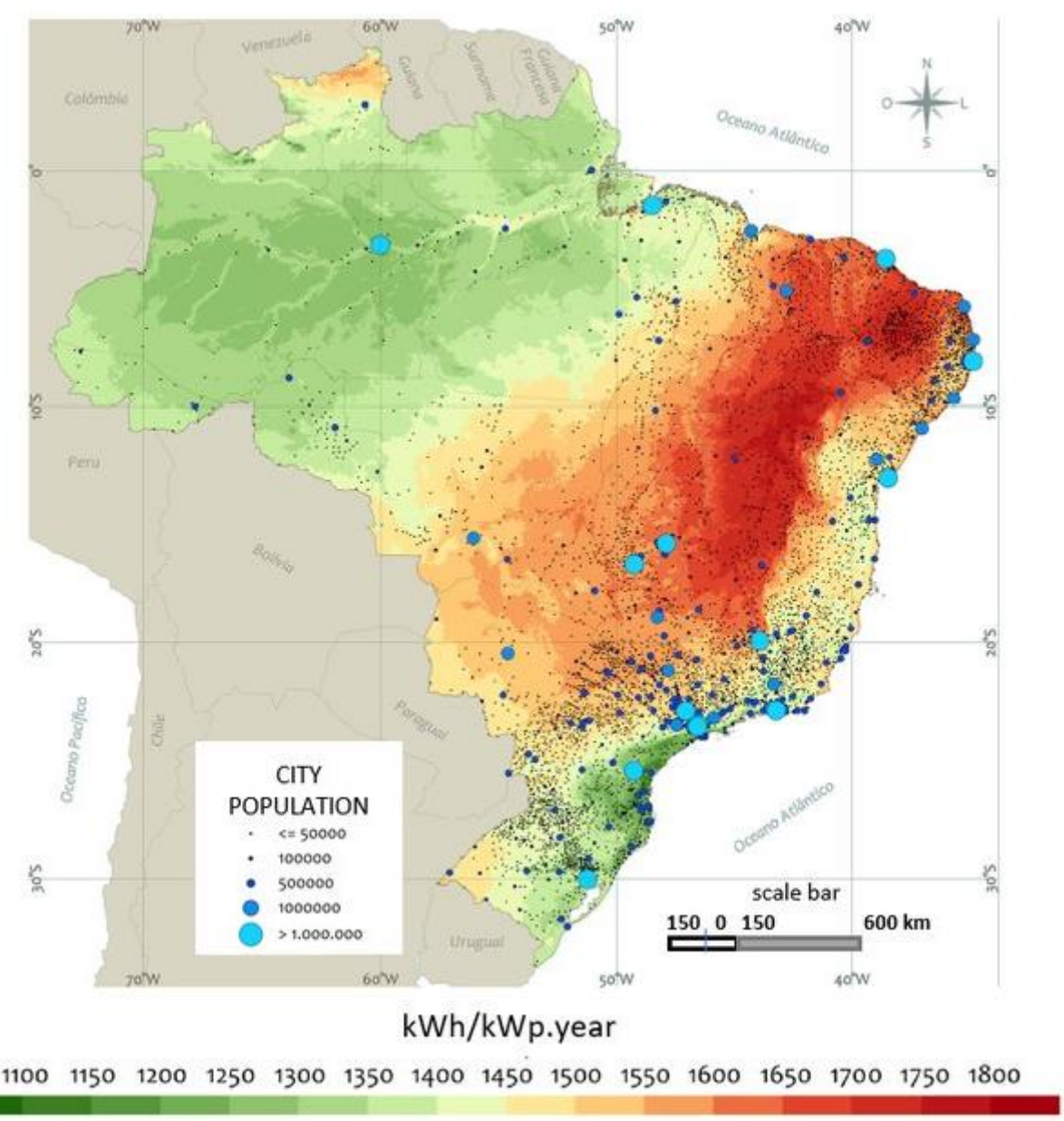

Figure 7. PV solar generation potential in Brazil [94].

According to Figure 7, the Northeast region of the country presents excellent levels of solar irradiation, mainly in the semiarid region, while in the South region, the highest levels of solar irradiation occur in the summer months, coinciding with the dry season in the region and with the period higher energy demand in this part of the country [95]. The Brazilian solar map shows the range varying between 1,100 to $1,800 \mathrm{kWh} / \mathrm{kWp}$.year depending on the region. According to [96] the Brazilian potential is comparable to several European countries such as Italy, Macedonia, Bulgaria, Croatia, etc., due to its similarity in terms of yearly irradiation levels around $5.9 \mathrm{kWh} / \mathrm{m}^{2}$ for solar Global Horizontal Irradiance [94]. These mentioned countries present a percentual difference regarding the annual average of $2.13 \%, 5.38 \%, 9.62 \%$, and $13.83 \%$ respectively compared to Brazil [97].

As mentioned before, only in 2012 the Brazilian regulatory agency ANEEL established the rules and regulations allowing the micro and mini generation installation (limited to $1000 \mathrm{kWp}$ ) through the Normative Resolution 482/2012. Thus, the agency adopted the energy compensation mechanism, in that a solar roof can be connected to the electrical grid through the Consumer Unit (UC) and inject the surplus in the electrical network, accumulating credits to be offset in $\mathrm{kWh}$. In 2016 the rated power limit was increased by the Normative Resolution 687/2015 to up to $5000 \mathrm{kWp}$ per UC (which is equivalent to the average consumption of middle-class homes in Brazil) [3, 98].

With the Normative Resolution 687/2015 reform, there were an extension in terms of consumers who want to install the PV systems. The extension enabled condominiums, associations, cooperative and also remote self-consumption consumers to apply these systems. Additionally, apartment units can generate solar electricity elsewhere in the case of a farm or beach house owned by the same apartment unit mentioned before, and then compensate the energy credits generated in apartments in the city. It can also be a condominium, cooperative, or consortium (consumer association) and install a community 
generator in a place other than the point of consumption of any tenants, cooperatives, or consortium members $[3,98]$.

In the case of large-scale applications and companies that operate installing PV systems, ANEEL offers incentives, where customers can order the installation of roof solar in their homes and pay the cost of this installation with the energy savings that the solar generator provides. With a scenario of increasing electricity tariffs and dropping solar roofs, this option becomes more and more interesting for the consumer [3].

On the other hand, ANEEL established that residential consumers denominated Group B with consumption above $250 \mathrm{kWh} /$ month will be able to pay different rates depending on the time and day of the week, based on time of use, so-called White Rate in Brazil. In this category, the tariff value varies within the concession area on working days at 3-time points: peak, intermediate and off-peak. The electricity tariff is costly at the peak, due to the demand at this time being higher, and lower during off-peak hours. Intermediate hours are usually defined at one hour before and one hour after the peak time defined by ANEEL, from $6 \mathrm{pm}$ to $9 \mathrm{pm}$ [99].

With this action, ANEEL can encourage consumers who have this requirement to modify their consumption profile, for off-peak and intermediate hours. Based on this initiative, the agency encourages the use of energy in periods when the distribution network has idle capacity, in addition to promoting actions to accelerate and develop the sector with increased use of renewable energies and battery storage systems integration.

Regarding the option of the White Tariff by the consumers, several studies have discussed and analyzed energy management through PV-battery-grid-tie systems. Azevedo et al., [100] use a mixed-integer linear programming model to identify the appropriate tariff modalities to minimize the electricity costs of consumers in Group B. Matias et al., [90] use a genetic algorithm to optimize the dispatch of energy considering the White Tariff in its analysis. Finotti et al., [101] developed a financial analysis of the application of PV-battery-grid-tie systems, comparing the conventional and White Tariff for the residential consumer.

Souza et al., [102], Junior et al., [103], Matias et al., [90] Azevedo et al., [100] Finotti et al., [101], Lupomo and Madruga [104] and Matias and Betini [105] emphasize the importance of the transition from the Brazilian tariff system to a scenario in which the tariff presents a dynamic variation, according to the time of use of electricity. In this sense, many developed countries use the Time of Use tariff, similar to the White Tariff, which encourages consumers to reduce peak demand by reducing their energy bills [106]. There are generally three periods during the day: peak hours, average hours, and off-peak hours [107].

In the Brazilian scenario, it still does not have specific regulations for the connection and operation of PV-battery-grid-tie systems. Energy storage service is a subject that is widely discussed by studies and surveys made from ANEEL's Strategic Call 21, mainly considering the billing regarding tariffs consumers can carry out. As a result, there is a consensus on the evolution of regulatory aspects, ensuring a fair relationship between consumers and the electricity company, encouraging the use and production of electricity, through renewable and decentralized generation sources [102].

Therefore, the reformulation of a public policy and the adoption of new sector regulations for the development and implementation of this technology on a large scale, requires a joint effort by R\&D, electricity companies, and ANEEL [103, 104]. In addition, the initiative contributes with relevant aspects to energy planning, these actions also aim to reduce costs and mitigate the problems associated with the implementation and operation of these systems.

\section{Market Challenges Framework}

Many countries have chosen to liberalize and decentralize all or part of their electricity markets. This decision allows consumers to compare offers and choose their suppliers according to their needs, services, and tariffs. With this decentralization, energy 
generators compete in the market to cater to the expected demand of customers, this competition results in the attraction of innovative and more efficient participants [27].

The global market for energy storage has grown rapidly even though there is difficulty in measuring how much. According to a widely publicized projection, the storage market could reach more than 26 billion US dollars in annual sales by 2022, a compound annual growth rate of 46.5 per cent [108]. Another study predicts more modest growth, but still robust with a compound annual growth rate of 16 per cent and reaching 7 billion US dollars annually by 2025 [109].

This divergence in growth rates is due to the way energy storage is defined. In some analyses, this value is determined considering only the scale of the technologies installed behind-the-meter, while others include solutions installed in front of the meter implemented by commercial companies and industrial customers. Despite the complexity of the scenario, the global growth projections for the energy storage systems are considered, and thus changing the dynamics of the energy market.

Countries like the United States of America (USA), Germany, China, Australia, Chile, Japan, India, Italy, South Korea, and the United Kingdom, have focused on storage systems. It is important to analyze the reason for boosting energy storage in these countries and what regulatory formulators have been doing to develop the market and support its implementation [110].

The location of the implementation of the storage systems generates changes in the value proposition for the stakeholders and the electric network. An example of storage systems applications due to their location and the system service in the USA, which is part of the electrical system, and can be applied in the Brazilian scenario [111]:

- Transmission level: generally characterized by higher voltages (in the range of 115 to $765 \mathrm{kV}$ ). This includes large central generation stations, transmission lines, transmission substations, or customers connected to the transmission.

- Distribution level: network distribution level includes medium voltage distribution lines, distribution substations, and commercial / industrial customers directly connected to the distribution through substations with voltages ranging from $4 \mathrm{kV}$ to $69 \mathrm{kV}$.

- Behind-the-meter: includes any storage at the customer's premises or near residential, commercial, or industrial buildings; also including electric vehicles.

Some examples of business models currently offered at these various levels include:

- Batteries connected to large-scale transmission implemented by companies such as AES and Eos Energy Storage, which allegedly competes directly with natural gas plants to define price compensation in the wholesale electricity market [112].

- Transportable modular energy storage deployed in distribution substations to postpone network updates, a highly researched application that some distributors have used [113].

- Located in the consumer: focused on reducing demand collection in some USA markets, by companies such as Tesla, Stem, Sunverge, and Coda [114].

in order to help stakeholders and policymakers around the world, Sandia Laboratories and the Rocky Mountain Institute have identified 13 services that can be offered by energy storage systems considering three stakeholders, and it is worth mentioning that this is just one model among many, as shown in Figure 8 [48, 115]. 


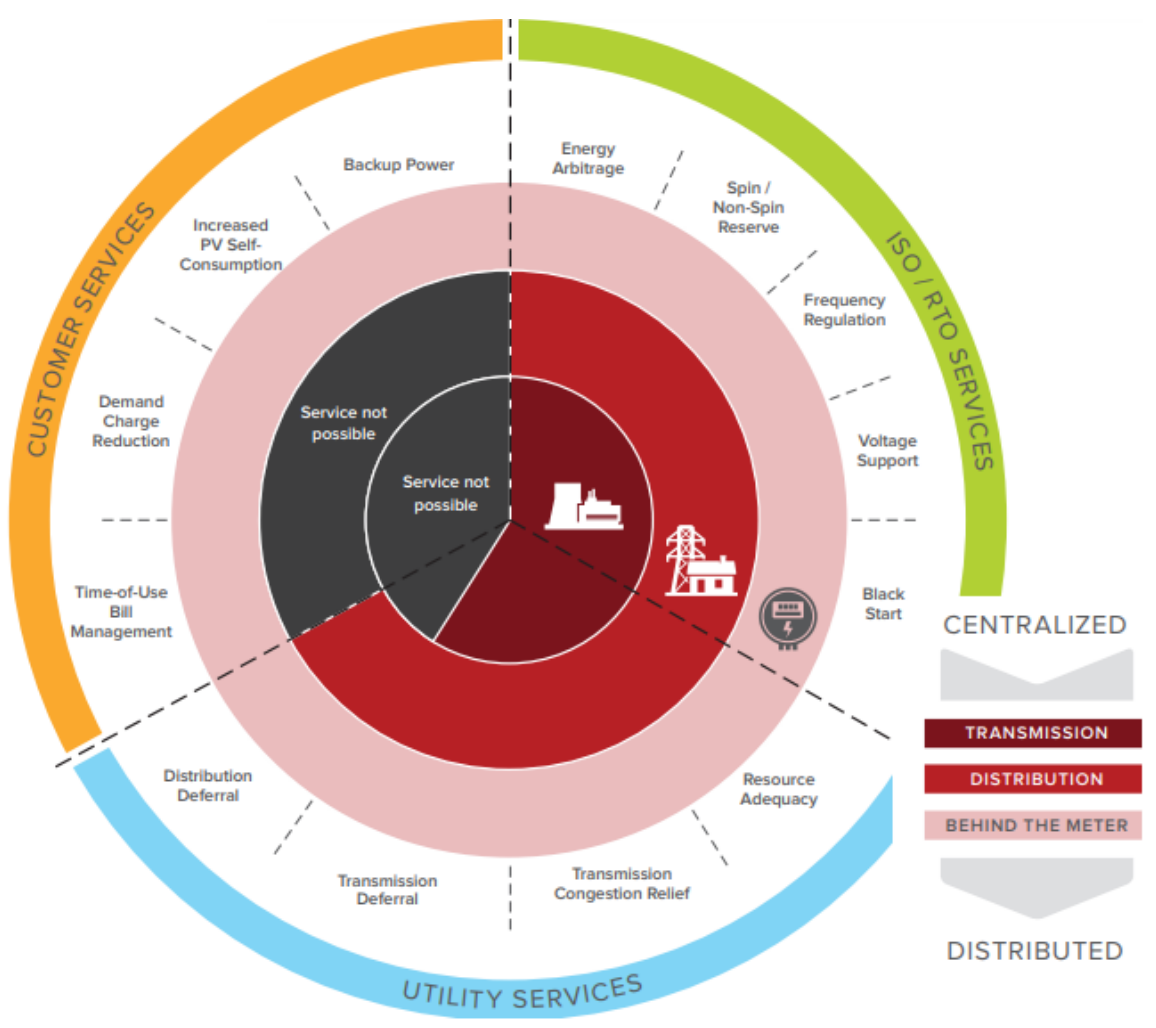

Figure 8. Services offered by the energy storage [115].

In addition, most systems deployed to date are comprised of single-use and underused batteries. Thus, a storage system must have dimensions to meet more than one of the services shown in Figure 7. For energy storage behind the meter that has the potential to provide multiple benefits to stakeholders in the electrical system, barriers to tariffs and pertinent regulations are barriers that prevent the spread of its use [115].

\subsection{Comprehensive Barriers}

Many transversal barriers prevent the storage system from providing various services to the electric network, such as [115]:

- Rules and regulations for storage systems behind the meter to have the same conditions as large generators. In addition, most companies do not consider energy storage and other distributed energy resources as a viable alternative to traditional infrastructure investments.

- Regulatory restrictions make it difficult or impossible for companies to collect revenue from an energy storage asset behind-the-meter for providing value to multiple stakeholders. The systems can provide services at different levels of the electrical network (transmission level, distribution level, and behind the meter) and to different stakeholders (Independent System Operators-ISOs and Regional Transmission Organizations-RTO, the network operators). For example, under current ISO / RTO standards, a utility would not be allowed to use a storage system to participate in the sale on the wholesale electricity market and to recover the costs of implementing the system.

- Most wholesale electricity markets pay service providers using the marginal cost of generation and opportunity with discretion. In this case, they do not include the cost of providing ancillary services such as energy storage.

\subsection{Regulatory Barriers for Specific Services and Recommendations}

In the Brazilian case, there are many regulatory barriers identified in this research with regards to specific areas and services such as: 
- Energy arbitrage (includes Load Following): operators cannot dispatch the energy storage system as a lower-cost operation, and they are not allowed to participate in the wholesale electricity market.

- Frequency and Spinning and Non- Spinning reserve: the regulatory uncertainty consists in the lack of clarity regarding its ability to participate in various markets.

- Voltage control and Black Start: there are no formal market structures instead, these services are compensated at a service cost rate approved by the Federal Energy Regulatory Commission (FERC).

- Deferral of updating the distribution network using a storage system, there is no mechanism to receive the amounts spent on this type of technology, only with traditional demand management programs.

Some recommendations are necessary for energy storage to be part of a safe, highrenewal, low-cost, low-carbon system for the grid of the future:

For Regulatory bodies:

- Remove barriers that prevent the use of energy storage with its various added services, to benefit the various stakeholders.

- Demand that distributed energy resources, including storage, be considered as an alternative, potentially low-cost solution to problems normally solved with traditional technologies and methods.

For Electricity Companies:

- Restructure models and rates so that the storage considers the temporal, local functionality, and its attributes, to match the distributed energy resources (DER) with the centralized ones.

- Before considering new centralized assets, check if it is possible to use storage systems with their multiple functionalities.

For the Scientific Community:

- Develop a detailed roadmap that specifies regulatory changes to allow for the broad integration of energy storage and other DERs.

For developers of storage systems and distributed energy resources:

- Pursue business models that fully utilize storage systems.

- Continue efforts to reduce the cost of energy storage systems (all $\$ / \mathrm{kW}$ components).

\subsection{Business Model Propose}

The climate change concerns, as well as energy security, have led different international and national bodies to start looking for safe energy alternatives. This has led to the insertion of renewable sources in the global energy matrix which has been widely supported. This energy transfer has promoted the dissemination of distributed energy resources (DER) that are usually in the consumers' facilities (behind-the-meter), and these customers are within the concession area of an energy distributor [116]. DER can be defined as electric energy generation and/or storage technologies with users:

- Distributed generation.

- Distributed energy storage.

- Demand response / Energy efficiency.

- Electric mobility.

The diffusion of DER in the market drove a change in the pattern of development of the electrical system, therefore, it is necessary to reformulate the current regulatory framework, as well as the role of the agents involved [117].

The change in regulation should aim to reduce the risks inherent in the diffusion of DER, and also promote the diversification of the distributor's business. These new business models will have distributors as their main active agent, either on the demand side or on the generation side [116].

For the case of demand, new forms of relationship with consumers are necessary, for example, demand response programs based on incentives or prices. This new business 
model requires the implementation of new tariff structures, as well as investments in infrastructure. Examples of relationship products and programs are:

- direct control of the load, with the definition of interruptive loads and demand offers.

- tariff for hours of use, peak tariff, and tariff in real-time.

According to Figure 6 on the supply side, three business models have been practiced in the USA [118]. In these business models, distributors can act as owners of assets, financiers of assets, or in contracting DER energy for resale [119].

According to [120], in the first model, distributors can carry out projects for installation, operation, and maintenance of photovoltaic panels in areas provided by customers as they own the generation assets, and the energy is injected into the network. Consumers are benefited by the means of a monthly fee for the rental of roofs (Rooftop Solar), but they continue to consume energy from the electricity company network. This business model allows distributors to recover the costs of operating and maintaining solar systems with the use of a tariff review and also to receive remuneration on generation assets such as panels and inverters.

The second business model serves the distributor's interests due to regulatory or economic-financial issues that do not own generation assets. The distributors offer loans and financing for consumers to purchase the generation systems, which is their role to facilitate it. It is important to mention that loans and financing are considered as investments in the tariff review. However, in this model, there are no credits and political incentives. Consumers can take advantage of the compensation system with the surplus energy injected into the network as they own the generated energy. This leads to a reduction in sales by distributors [120]. In the case of regulated distributors, it is their responsibility to operate and maintain the network infrastructure, and thus adopting specific rates for consumers.

In the latest business model, distributors use bilateral contracts (Power Purchase Agreement - PPA) to contract energy from RED to resell to their consumers. With these contracts, the energy price is shielded from any market fluctuation, so there is no risk to the operation and maintenance of generation for the distributors [120]. This business model is similar to the energy auctions in Brazil that meet certified targets used to prove the production of one MWh of electricity from renewable sources. In this case, these contracts are considered as the cost of the distributor.

The business models are very comprehensive, and it is not interesting for electricity companies to act using extreme measures, which is as owners and operators of the DER assets installed in the consumer units and also as owners of the wire. The hybrid model is the most suitable, and some intermediate options can be listed [116]:

- Distributor as a provider of solutions for third parties.

- Division of functions by-product or scope of activities.

- Distributor competing with third parties.

- Distributor operating micro platforms.

\subsection{National scenario for Research and Development}

In recent years, demographic growth, and economic activities in Brazil, among other factors, have resulted in a constant increase in the country's electricity consumption. In addition to this growth, climatic factors such as long periods of drought that severely affect hydraulic generation show that traditional energy sources are insufficient to meet the current and future needs of the country. It demonstrates that alternatives are imperative to respond to these needs and allow the expansion and diversification of the country's energy matrix.

In this situation, accordingly with the global objectives of clean and sustainable energy production, the insertion of DG and the use of renewable energy sources (RES) by residential, commercial, and industrial consumers have recently been encouraged in Brazil as a solution to the energy supply problems. The Brazilian government through the National Electric Energy Agency (ANEEL) has directed efforts to create conditions that 
promote this insertion. An example of this is Normative Resolution 482 [121], subsequently amended by Normative Resolution 687 [98] and Section 3.7 "Access to Micro and Mini Distributed Generation" of Distribution Procedures (PRODIST) module 3 [122], which establishes the general conditions for accessing the micro and mini generation distributed to the electricity distribution systems and defines net compensation (similar to net metering) as a system which regulates the energy exchange between the consumer and the electricity utility [123].

Technical note 0056/2017 - SRD / ANEEL [123] presents results that show the evolution of this implementation since the publication of the normative resolution in 2012. Although the insertion of these sources shows an important growth in the last years, this is still below expectations; as it can still be considered insufficient and there is an opportunity for greater sustainable development, as indicated in the 10-year Energy Expansion Plan (PDE) 2026 [124]. The business conditions of the normative resolution 482 of 2012 [121] which, despite being improved with the revision of the normative resolution 687 of 2015 [98] are not attractive to the consumer. As well, to add to the fact that the rules that define the energy tariff system and the Net compensation are presented confusingly, without being able to clearly quantify the return on investment by consumers and suppliers of DG sources.

They constitute some of the main barriers that have slowed the DG implementation. To overcome these barriers, an alternative is an integration of energy storage systems (ESSs) with renewable energy sources (RESs), and the development optimization and controlled algorithms that make it possible to efficiently manage the energy sources that the consumer has available and has exchanged that energy with the electricity company. This is an attractive solution, which if developed correctly, can reconcile the economic benefits for the consumer with the technical and operational for the network and the concessionaire [125].

In this context, the development of solutions for the management of ESSs of the captive consumers, considering the specifications of the Brazilian context is a promising and relevant line of action to effectively leverage the insertion of DG and RES sources by conventional energy consumers. In its Strategic Call no 021/2016, ANEEL [28], following the global trend of arousing the interest of research institutions, technology manufacturers, and electric energy companies, as a strategy to stimulate the development and application of technologies and storage systems.

In addition, Regulatory Activity Agenda 106 [126] aims to prepare the regulation for the expansion of distributed energy resources, this is a theme classified as sector structure or transversal, as they affect more than one segment. This agenda presents notes on topics directly and indirectly related to DG and energy storage. It is organized in the modalities of distribution, transmission, generation, commercialization, and market, economic and financial regulation and accounting of the Electric Sector, tariff, R\&D and energy efficiency, sector structure or transversal, and ANEEL organization.

When the document was launched, the main areas or groups affected by the regulatory activity had already been identified, namely distributors, transmitters, generators, and consumers. The characteristics of this activity are a prospective and feasibility study. Through prospective and feasibility studies, the activity aims to bring together agents and society to analyze what actions should be taken concerning to energy storage systems and what adjustments should be made in the current regulatory framework.

This activity is related to the theme in question and represents that in the next year that there will be discussions about ESSs. However, it still does not appear as a topic of relevance for the Brazilian electricity sector since its priority appears as "indicative" and the agenda to be addressed is quite comprehensive. Nevertheless, the issue of regulation of this type of equipment in Brazil will be addressed in more depth shortly.

\section{Conclusions}


This paper examines three key areas with regards to the implementation of widespread electric energy storage. To start, grid operators must have confidence that the energy storage systems will perform as expected within a larger network. However, there are energy regulatory problems with the grid, especially at a large capacity since these systems provide different benefits with their functions which leads to unpredictability which poses an investment risk. In summary, energy storage investments require a mutual understanding and cooperation from different areas such as electric utilities, facilities, technology owners, investors, project developers, and insurers, since there are different perspectives on the situation which leads to more collaboration.

Regarding battery technologies, lead-acid is a widely accepted and more mature technology, although there is still a great deal of research and development carrying out worldwide aiming to improve their characteristics. The main reasons for this effort are the low initial cost, its recycling, which is practically totally and economically viable (and particularly important, for drastically reducing the dependence on new materials extracted from nature). It is the only type of battery with a well-developed in the national scenario, which generates even greater relevance for the Brazilian case.

The possible new demand for stationary lithium-ion batteries and partial electrification of the vehicle fleet, the constant consumption of portable electronics in Brazil, added to the scarcity of raw materials in and growing concern with environmental impacts practically oblige the expansion of the battery recycling industry. Given the national characteristics, it is understood that this is an opportunity for the local industry to develop and contribute to the dissemination of the use of energy storage systems in the electricity grid.

The next generations of batteries should have electrical properties superior to the current lithium ion and / or lower price. On the other hand, the flow batteries have maximum electrical properties lower than the current lithium ions but use cheaper and abundant raw materials and also have a simpler manufacturing process, for this reason, they have the potential to present a lower initial cost in the future.

It highlights the transformations facing the electricity sector in recent years, through disruptive technologies that have made consumers more engaged. Thus, it is necessary to study regulatory models that need to be defined by the regulator (ANEEL), such as technical criteria, economic incentives, the role of various agents in the electricity sector, cost recognition, tariff setting, among others. These criteria have already been adopted in other countries to address current innovations in the electricity sector and to assess the relevance of proposing new regulations.

Additionally, a great effort was identified under development along with ANEEL R\&D Strategic Call no 021/2016 with regards to regulatory market. In conclusion, the lack of regulation must deal with the provision of services by RES for the distribution network, including their remuneration, which hinders the possible business models that would make the expansion of RES possible. In the future, more efforts can be devoted to tariff incentives, as well as regulation changes or international regulatory adaptation.

Author Contributions: Conceptualization, J.D.M., P.M.B.F and L.M.; Project Administration, P.A.B.B. and V.B.R.; Funding Acquisition, J.T.; Methodology, J.D.M. and P.M.B.F.; Resources, J.D.M., P.M.B.F and L.M.; Visualization, V.B.R. and L.M.; Writing-original draft preparation, J.D.M., P.M.B.F and L.M.; Writing - review and editing, J.D.M., L.M. and V.B.R.; All authors have read and agreed to the published version of the manuscript. 
Funding: The authors would like to thank the CPFL group for technical and financial support, through the Research and Development project PD-02937-3018/2016 with resources from ANEEL's R\&D program.

Acknowledgments: The authors would like to thank the Lactec Institute and CPFL. The authors also thank UTFPR for the support and infrastructure provided for the development of this research.

Conflicts of Interest: The authors declare no conflict of interest.

\section{References}

1. Rüther, R. Edifícios Solares Fotovoltaicos: o potencial da geração solar fotovoltaica integrada a edificações urbanas e interligada a rede elétrica pública no Brasil, 1st ed.; UFSC, Florianópolis, Brazil, 2004.

2. ANEEL. National Electric Energy Agency. 2021. Unidades consumidoras com geração distribuída. Available online: https://www.aneel.gov.br/outorgas/geracao/-/asset publisher/m/hnKIi7qcJG/content/registro-de-central-geradora-de-capacidade-reduzida/655808?inheritRedirect=false\&redirect=https $\% 3 \mathrm{~A} \% 2 \mathrm{~F} \% 2 \mathrm{Fwww}$.aneel.gov.br $\% 2$ Foutorgas $\% 2 \mathrm{Fgera}-$ cao\%3Fp p id\%3D101 INSTANCE m/hnKIi7qcJG\%26p p lifecycle\%3D0\%26p p state\%3Dnormal\%26p_p_mode $\% 3 D v i e w \% 26 p \_p \_c o l \_i d \% 3 D$ column-2\%26p_p_col_pos $\% 3 D 1 \% 26 p \_p \_c o l \_c o u n t \% 3 D 2$ (accessed on 22 April 2021).

3. Pereira, E.B.; Martins, F.R.; Gonçalves, A.R.; Costa, R.S.; Lima, F.J.L.d.; Ruther, R.; Abreu, S.L.d.; Tiepolo, G.M.; Pereira, S.V.; Souza, J.G.d. Atlas Brasileiro de Energia Solar; Instituto Nacional de Pesquisas Espaciais, INPE: São Jose Dos Campos, Brazil, 2017.

4. Olubunmi, O. A.; Xia, P. B.; Skitmore, M. Green building incentives: A review. Renew. and Sust. Ener. Rev., 2016, 59, 1611-1621. [CrossRef]

5. Dwaikat, L. N.; Ali, K. N. Green buildings cost premium: A review of empirical evidence. Ener. and Build., 2016, 110, $396-403$. [CrossRef]

6. Urbanetz Jr, J. Sistemas Fotovoltaicos Conectados a Redes de Distribuição Urbanas: sua influência na qualidade da energia elétrica e análise dos parâmetros que possam afetar a conectividade. PhD Dissertation, Federal University of Santa Catarina, Florianópolis, 2010.

7. Parida, B.; Iniyan, S.; Goic, R. A review of solar photovoltaic Technologies. Renew. and Sust. Ener. Rev. 2011, 15, 1625-1636. [CrossRef]

8. Villalva, M. G.; Gazoli, J. R. Energia Solar Fotovoltaica: conceitos e aplicações, 2nd., Érica Ltda, São Paulo, Brazil, 2015.

9. Kannan, N.; Vakeesan, D. Solar energy for future world: -A review. Renew. and Sust. Ener. Rev., 2016, 62, 1092-1105. [CrossRef]

10. Zilles, R.; Macêdo, W. N.; Galhardo, M. A. B.; de Oliveira, S. H. F. Sistemas fotovoltaicos conectados à rede elétrica, 1st ed.; Oficina de Textos, São Paulo, Brazil, 2016.

11. Pinho, J. T.; Galdino, M. A. Manual de engenharia para sistemas fotovoltaicos, 2nd ed.; CEPEL-CRESESB, Rio de Janeiro, Brazil, 2014; $1-529$.

12. Sampaio, P. G. V.; González, M. O. A. Photovoltaic solar energy: Conceptual framework. Renew. and Sust. Ener. Rev., 2017, 74, 590-601. [CrossRef]

13. Sechilariu, M.; Wang, B.; Locment, F. Building integrated photovoltaic system with energy storage and smart grid communication. IEEE Trans. on Ind. Elect., 2012, 60, 1607-1618. [CrossRef]

14. Sechilariu, M.; Wang, B.; Locment, F. Building-integrated microgrid: Advanced local energy management for forthcoming smart power grid communication. Ener. and Build., 2013, 59, 236-243. [CrossRef]

15. Wang, Z.; Gu, C.; Li, F. Flexible operation of shared energy storage at households to facilitate PV penetration. Renew. Ener. 2018, 116, 438-446. [CrossRef]

16. Munzke, N.; Schwarz, B.; Barry, J. The Impact of Control Strategies on the Performance and Profitability of Li-Ion Home Storage Systems. Ener. Proc. 2017, 135, 472-481. [CrossRef]

17. Afxentis S.; Florides M.; Yianni C.; Efthymiou V.; Papageorgiou I.; Partasides G.; Papagiannis G.; Christoforidis G.; Mocci S.; Rubiu A.; Oliveira J. Promotion of higher penetration of distributed PV through storage for all (StoRES). In International Congress on Engineering and Sustainability in the XXI Century, Springer, Cham, Oct 11 2017, 479-488. [CrossRef]

18. Opiyo, N. Energy storage systems for PV-based communal grids. Jour. of Ener. Stor. 2016, 7, 1-12. [CrossRef]

19. Jangjun, C.; Chuangchote, S.; Bangviwat, A.; Chenvidhya, D. Load Profiles in Grid-Connected Residential Buildings: Experimental Studies with Rooftop PV and Battery Systems. Suan Suna. Scie. and Tech. Jour., 2019, 6, 12-20. [CrossRef]

20. Almazrouei, S.; Hamid, A. K.; Mehiri, A. Energy Management for Large-Scale Grid Connected PV-Batteries System. International Renewable and Sustainable Energy Conference (IRSEC), Tangier, Morocco, Dec 4-7 2017, 1-5. [CrossRef]

21. Skrylnyk, O.; Lepore, R.; Ioakimidis, C. S.; Remy, M.; Frere, M. State-of-charge observers for lead-acid storage units used in autonomous solar applications. Jour. of Ener. Stor., 2017, 14, 1-7. [CrossRef]

22. Saglamer, U. C. Evaluation of photovoltaic technologies with electrochemical energy storage for residential usage and economic considerations. Master's Dissertation, Polytechnic University of Milan, 2017.

23. Reimuth, A.; Prasch, M.; Locherer, V.; Danner, M.; Mauser, W. Influence of different battery charging strategies on residual grid power flows and self-consumption rates at regional scale. App. Ener., 2019, 238, 572-581. [CrossRef]

24. Chiaroni, D.; Chiesa, V.; Franzò, S.; Frattini, F. Evaluating battery energy storage systems: An analysis of their adoption with photovoltaic plants in Italy. IEEE 16th International Conference on Environment and Electrical Engineering (EEEIC), Florence, Italy, June 2016. 1-6. [CrossRef] 
25. Mishra, A.; Irwin, D.; Shenoy, P.; Kurose, J.; Zhu, T. Smartcharge: Cutting the electricity bill in smart homes with energy storage. Proceedings of the 3rd International Conference on Future Energy Systems: Where Energy, Computing and Communication Meet, Madrid, Spain, May 2012. 1-10. [CrossRef]

26. Zhu, T.; Huang, Z.; Sharma, A.; Su, J.; Irwin, D.; Mishra, A.; Shenoy, P. Sharing renewable energy in smart microgrids. 2013 ACM/IEEE International Conference on Cyber-Physical Systems (ICCPS), Philadelphia, PA, USA, April 2013, $219-228$.

27. Burin, H.P., Siluk, J.S., Rediske, G. and Rosa, C.B. Determining Factors and Scenarios of Influence on Consumer Migration from the Regulated Market to the Deregulated Electricity Market. Ener., 2021, 14, 65. [CrossRef]

28. ANEEL. National Electric Energy Agency. 2019. Projeto Estratégico: “Arranjos Técnicos e Comerciais Para a Inserção de Sistemas de Armazenamento de Energia no Setor Elétrico Brasileiro". Available online: http://www.aneel.gov.br/documents/656831/14930433/Chamada+PD Estrategico 21 Armazenamento Julho2016/0210802b-b6a6-4ed5-aa9e-2ec3911f7b44, (accessed on 26 October 2019).

29. Akbari, H.; Browne, M. C.; Ortega, A.; Huang, M. J.; Hewitt, N. J.; Norton, B.; McCormack, S. J. Efficient energy storage technologies for photovoltaic systems. Sol. Ener., 2018, 192, 144-168. [CrossRef]

30. Üçtuğ, F. G.; Azapagic, A. Environmental impacts of small-scale hybrid energy systems: Coupling solar photovoltaics and lithium-ion batteries. Scien. of the Tot. Envir., 2018, 643, 1579-1589. [CrossRef]

31. Hassan, A. S.; Cipcigan, L.; Jenkins, N. Optimal battery storage operation for PV systems with tariff incentives. Appl. Ener., 2017, 203, 422-441. [CrossRef]

32. Nottrott, A.; Kleissl, J.; Washom, B. Energy dispatch schedule optimization and cost benefit analysis for grid-connected, photovoltaic-battery storage systems. Renew. Ener., 2013, 55, 230-240. [CrossRef]

33. Gitizadeh, M.; Fakharzadegan, H. Battery capacity determination with respect to optimized energy dispatch schedule in gridconnected photovoltaic (PV) systems. Ener., 2014, 65, 665-674. [CrossRef]

34. Lawder, M. T.; Viswanathan, V.; Subramanian, V. R. Balancing autonomy and utilization of solar power and battery storage for demand based microgrids. Jour. of Pow. Sour., 2015, 279, 645-655. [CrossRef]

35. Lee, S. B.; Pathak, C.; Ramadesigan, V.; Gao, W.; Subramanian, V. R. Direct, efficient, and real-time simulation of physics-based battery models for stand-alone pv-battery microgrids. Jour. of The Electro. Soc., 2017, 164, E3026-E3034. [CrossRef]

36. Hanna, R.; Kleissl, J.; Nottrott, A.; Ferry, M. Energy dispatch schedule optimization for demand charge reduction using a photovoltaic-battery storage system with solar forecasting. Sol. Ener., 2014, 103, 269-287. [CrossRef]

37. Mulder, G.; Six, D.; Claessens, B.; Broes, T.; Omar, N.; Van Mierlo, J. The dimensioning of PV-battery systems depending on the incentive and selling price conditions. Appl. Ener., 2013, 111, 1126-1135. [CrossRef]

38. Rahimi-Eichi, H.; Ojha, U.; Baronti, F.; Chow, M. Y. Battery anagement system: An overview of its application in the smart grid and electric vehicles. IEEE Ind. Electr. Mag., 2013, 7, 4-16. [CrossRef]

39. Cheng, K. W. E.; Divakar, B. P.; Wu, H.; Ding, K.; Ho, H. F. Battery-management system (BMS) and SOC development for electrical vehicles. IEEE Trans. on Vehic. Tech., 2010, 60, 76-88. [CrossRef]

40. Lawder, M. T.; Suthar, B.; Northrop, P. W. De, S.; Hoff, C. M.; Leitermann, O.; Subramanian, V. R. Battery energy storage system (BESS) and battery management system (BMS) for grid-scale applications. Proce of the IEEE, 2014, 102, 1014-1030. [CrossRef]

41. Xing, Y.; Ma, E. W.; Tsui, K. L.; Pecht, M. Battery management systems in electric and hybrid vehicles. Ener., 2011, 4, 1840-1857. [CrossRef]

42. Gallardo-Lozano, J.; Romero-Cadaval, E.; Milanes-Montero, M. I.; Guerrero-Martinez, M. A. Battery equalization active methods. Jour. of Pow. Sour., 2014, 246, 934-949. [CrossRef]

43. Lo, K. Y.; Chen, Y. M.; Chang, Y. R. Bidirectional single-stage grid-connected inverter for a battery energy storage system. IEEE Trans. on Ind. Electr., 2016, 64, 4581-4590. [CrossRef]

44. Debnath, D.; Chatterjee, K. Solar photovoltaic-based stand-alone scheme incorporating a new boost inverter. IET Pow. Electr., 2016, 9, 621-630. [CrossRef]

45. Balcombe, P.; Rigby, D.; Azapagic, A. Energy self-sufficiency, grid demand variability and consumer costs: Integrating solar PV, Stirling engine CHP and battery storage. Appl. Ener., 2015, 155, 393-408. [CrossRef]

46. Feng, X.; Gooi, H. B.; Chen, S. Capacity fade-based energy management for lithium-ion batteries used in PV systems. Elect. Pow. Syst. Resea., 2015, 129, 150-159. [CrossRef]

47. Hanser, P.; Lueken, R., Gorman, W.; Mashal, J.; Group, T. B. The practicality of distributed PV-battery systems to reduce household grid reliance. Util. Pol., 2017, 46, 22-32. [CrossRef]

48. Akhil, A. A.; Huff, G.; Currier, A. B.; Kaun, B. C.; Rastler, D. M.; Chen, S. B.; Gauntlett, W. D. DOE/EPRI 2013 electricity storage handbook in collaboration with NRECA. Albuquerque, NM, Sandia National Laboratories, 2013, 1-340.

49. Mahlia, T. M. I.; Saktisahdan, T. J.; Jannifar, A.; Hasan, M. H.; Matseelar, H. S. C. A review of available methods and development on energy storage; technology update. Renew. and Sust. Ener. Rev., 2014, 33, 532-545. [CrossRef]

50. Luo, X.; Wang, J.; Dooner, M.; Clarke, J. Overview of current development in electrical energy storage technologies and the application potential in power system operation. Appl. Ener., 2015, 137, 511-536. [CrossRef]

51. Kousksou, T.; Bruel, P.; Jamil, A.; El Rhafiki, T.; Zeraouli, Y. Energy storage: Applications and challenges. Sol. Ener. Mat. and Sol. Cel., 2014, 120, 59-80. [CrossRef]

52. Ecoult UltraBattery the new dimension in lead-acid battery technology', Available online: http://www.ecoult.com/technology/ultrabattery/, (accessed on 31 October 2019).

53. Akinyele, D. O.; Rayudu, R. K. Review of energy storage technologies for sustainable power networks. Sust. Ener. Tech. and Asses., 2014, 8, 74-91. [CrossRef] 
54. Goodenough, J. B.; Park, K. S. The Li-ion rechargeable battery: a perspective. Jour. of the Ame. Chem. Soc., 2013, 135, 1167-1176. [CrossRef]

55. Suberu, M. Y.; Mustafa, M. W.; Bashir, N. Energy storage systems for renewable energy power sector integration and mitigation of intermittency. Renew. and Sust. Ener. Rev., 2014, 499-514. [CrossRef]

56. Purvins, A.; Sumner, M. Optimal management of stationary lithium-ion battery system in electricity distribution grids. Jour. of Pow. Sour., 2013, 242, 742-755. [CrossRef]

57. Zhang, C.; Wei, Y. L.; Cao, P. F.; Lin, M. C. Energy storage system: Current studies on batteries and power condition system. Renew. and Sust. Ener. Rev., 2018, 82, 3091-3106. [CrossRef]

58. Nitta, N.; Wu, F.; Lee, J. T.; Yushin, G. Li-ion battery materials: present and future. Mat. Tod., 2015, 18, 252-264, 2015. [CrossRef]

59. Parasuraman, A.; Lim, T. M.; Menictas, C.; Skyllas-Kazacos, M. Review of material research and development for vanadium redox flow battery applications. Electro. Act., 2013, 101, 27-40. [CrossRef]

60. Aneke, M.; Wang, M. Energy storage technologies and real life applications-A state of the art review. Appl. Ener., 2016, 179, 350-377. [CrossRef]

61. Nguyen, T.; Savinell, R. F. Flow batteries. The Electro. Soc. Int., 2010, 19, 54-56. [CrossRef]

62. Kolokotsa, D. The role of smart grids in the building sector. Ener. and Build., 2016, 116, 703-708. [CrossRef]

63. Wurtz, F.; Delinchant, B. "Smart buildings" integrated in "smart grids": A key challenge for the energy transition by using physical models and optimization with a "human-in-the-loop" approach, Com. Ren. Phy., 2017, 18, 428-444. [CrossRef]

64. Ahmad, M. W.; Mourshed, M.; Mundow, D.; Sisinni, M.; Rezgui, Y. Building energy metering and environmental monitoringA state-of-the-art review and directions for future research. Ener. and Build., 2016, 120, 85-102. [CrossRef]

65. Serra, E. T.; de Faro Orlando, A.; Acher Mossé, N. M. Armazenamento de energia: Situação atual, perspectivas e recomendações. Comitê De Energia Da Academia Nacional De Engenharia, 2016, 1, 1-46.

66. Awad, A. S.; Fuller, J. D.; El-Fouly, T. H.; Salama, M. M. Impact of energy storage systems on electricity market equilibrium. IEEE Trans Sust. Ener., 2014; 5, 875-885. [CrossRef]

67. Castillo, A.; Gayme, D. F. Grid-scale energy storage applications in renewable energy integration: A survey. Ener. Conv. and Manag., 2014, 87, 885-894. [CrossRef]

68. Katiraei, F.; Chang, T.; Sun, C. Accidental islanding of distribution systems with multiple distributed generation units of various technologies. In Symposium Grid of the Future, Boston, USA, October 2013, 1-20.

69. Uddin, M.; Romlie, M. F.; Abdullah, M. F.; Abd Halim, S.; Kwang, T. C. A review on peak load shaving strategies. Renew. and Sust. Ener. Rev., 2018, 82, 3323-3332. [CrossRef]

70. Wang, G.; Ciobotaru, M.; Agelidis, VG. Power smoothing of large solar PV plant using hybrid energy storage. IEEE Trans. on Sust. Ener., 2014, 5, 834-842. [CrossRef]

71. Alam, MJE.; Muttaqi, KM.; Sutanto, D. A novel approach for ramp-rate control of solar PV using energy storage to mitigate output fluctuations caused by cloud passing. IEEE Trans. on Ener. Conv., 2014; 29, 507-518. [CrossRef]

72. Singh, B.; Chandra, A.; Al-Haddad, K. Power quality: problems and mitigation techniques. John Wiley \& Sons, 2014.

73. Rudolf, V.; Papastergiou, K. D. Financial analysis of utility scale photovoltaic plants with battery energy storage. Ener. Pol., 2013; 63, 139-46. [CrossRef]

74. Silva, J. E. D.; Santos, F. R.; Kaltmaier, G.; Urbanetz Junior, J. Implementation of a Photovoltaic Panel to Supply Electric Cars Energy Demands. Braz. Arch. of Bio. and Tech., 2018, 61, 1-7. [CrossRef]

75. Silva, J. E. D. Veículos elétricos e a geração distribuída a partir de sistemas fotovoltaicos. Master's Thesis, Federal University of Technology - Paraná, Curitiba, 2019.

76. Renewable Energy Integration Facility (REIF), Available online: https://www.csiro.au/en/Research/EF/Areas/Facilities/REIF?ref=/CSIRO/Website/Research/EF/Areas/Grids-and-storage/Energy-storage/REIF, (accessed on 29 November 2020).

77. Implementation of a PV rural micro grid in the island of Santo Antão (Cape Verde) with an individual energy allowance scheme for demand control, Available online: http://www.ecowrex.org/document/implementation-pv-rural-micro-grid-island-santoantao-cape-verde-individual-energy, (accessed on 29 November 2020.

78. Solibra Energy Storage System, Available online: http://www.vanadiumredoxflow.com/references/, (accessed on 29 November 2020).

79. Indian blackout held no fear for small hamlet where the power stayed on, Available online: https://www.theguardian.com/world/2012/sep/10/india-hamlet-where-power-stayed-on, (accessed on 29 November 2020).

80. UniEnergy Technologies Announces Next Utility Deployment of UniSystem (TM) with Terna in Sicily, Italy, Available online: https://www.prnewswire.com/news-releases/unienergy-technologies-announces-next-utility-deployment-of-unisystemtmwith-terna-in-sicily-italy-300255968.html, (accessed on 29 November 2020).

81. Effect of energy storage device for peak reduction, Available online: https://www.wjis.co.kr/kr/business/energy_storage reduction.php, (accessed on 29 November 2020).

82. Vodafone uses Redflow batteries to store energy for remote telecom tower site in New Zealand, Available online: https://redflow.com/vodafone-new-zealand-uses-redflow-batteries-for-remote-energy-storage-on-the-coromandel-peninsula/\#more9575, (accessed on 29 November 2020).

83. Dutt Powe Electronics and Control, Available online: http://www.duttelectronics.com/es/, (accessed on 29 November 2020).

84. Isle of Eigg PV Extension, Available online: http://www.windandsun.co.uk/case-studies/islands-mini-grids/isle-of-eigg-pv-extension.aspx\#.X-pBIVVKjIU, (accessed on 29 November 2020).

85. DOE OE Global Energy Storage Database, Available online: https://www.sandia.gov/ess-ssl/global-energy-storage-databasehome/, (accessed on 29 November 2020). 
86. Mocelin, A. R. Qualificação profissional e capacitação laboratorial em sistemas fotovoltaicos. PhD Dissertation, University of São Paulo, São Paulo, 2014.

87. Rüther, R. Um investimento = Múltiplas funções: desenvolvimento e avaliação técnica, regulatória e econômica de sistemas de armazenamento de energia aplicados a sistemas de geração centralizada e distribuída, In Workshop Minirredes de Geração e Sistemas de Armazenamento de Energia Elétrica. São Paulo, Brazil, 2017, 1-45.

88. Pinho, J. T. Infraestruturas laboratoriais do GEDAE/UFPA e do LSF/USP para o estudo de minirredes inteligentes em geração híbrida de energia. In Workshop Minirredes de Geração e Sistemas de Armazenamento de Energia Elétrica. São Paulo, Brazil, 2017, 1-40.

89. Ferronato, F. A. S. Sistema de supervisão e controle de fontes de energia renováveis e armazenamento de energia conectado em baixa tensão. Master's Thesis, Federal University of Paraná, Curitiba, 2014.

90. Matias, J. A. C.; Aoki, A. R.; Riboldi, V. B. Deslocamento de carga aplicado à sistema fotovoltaico com armazenamento de energia em baterias utilizando algoritmos genéticos. In VII Congresso Brasileiro de Energia Solar. VII CBENS, Gramado, Brazil, April 2018, 1-12.

91. Blasi, T. M. Análise Elétrica dos Impactos da Conexão de Sistemas Fotovoltaicos com Baterias na Rede de Distribuição, Electrical Engineer Final Course Completion, Federal University of Paraná, Curitba, 2017.

92. Mariano, J. D.; Urbanetz Junior, J. Photovoltaic battery buildings: a case of study at the Brazilian scenario. In $6^{\mathrm{a}}$ Conferência Internacional de Energias Inteligentes, Curitiba, Brazil, November 2019, 1-8.

93. Souza, A. S.; Mariano, J. D.; Urbanetz Junior, J. Sistema Fotovoltaico de 10kWp Conectado à Rede com Armazenamento e Energia em Curitiba. In VIII Congresso Brasileiro de Energia Solar, Fortaleza, Brazil, June 2020, 1-9.

94. Murari, T.B.; Moret, M.A.; Pitombo, S.; Santos, A.A. Self-Affine Analysis of ENSO in Solar Radiation. Ener., $2020,13,4816$. [CrossRef]

95. Montenegro, A. A. Avaliação do Retorno do Investimento em Sistemas Fotovoltaicos Integrados a Residências Unifamiliares Urbanas no Brasil. Master's Thesis, Federal University of Santa Catarina, Florianópolis, 2013.

96. Huld, T.; Pascua, I. P. Photovoltaic Solar Electricity Potential in European Countries. European Commission, Joint Research Centre, Institute for Energy and Transport, Renewable Energy Unit, 2012.

97. Tiepolo, G. M.; Pereira, E. B.; Urbanetz JR, J.; Pereira, S. V.; Goncalves, A. R.; Lima, F. J. L.; Costa, R. S., Alves, A. R. Atlas de Energia Solar do Estado do Paraná. 1st Ed. UTFPR: Curitiba, 2017, 1-107.

98. ANEEL. National Electric Energy Agency. 2015. Normative Resolution 687, Available online: https://www2.aneel.gov.br/cedoc/ren2015687.pdf, (accessed on 30 November 2020).

99. ANEEL. National Electric Energy Agency. 2015. White Tariff. Available online: https://www.aneel.gov.br/tarifa-branca, (accessed on 11 November 2019).

100. Azevedo, R. M.; Canha, L. N.; Brignol, W. S. Medeiro, A.; Garcia, V. J.; Santana, T. A. S. Análise sobre o Home Energy Management com sistemas de geração distribuída fotovoltaica e armazenamento no sistema de compensação de energia elétrica brasileiro. In $11^{\circ}$ Congresso Brasileiro de Planejamento Energético. XI CBPE, Cuiabá, 2018, 1-14.

101. Finotti, A. S.; Almeida, M. P.; Zilles, R. Simulação do Uso de Baterias Adotando a Tarifa Branca para Microgeração Fotovoltaica de Classe Residencial. In VII Congresso Brasileiro de Energia Solar. VII CBENS, Gramado, 2018, 1-5.

102. Souza, Kauê J. F. N. C. d.; Manito, A. R. A.; Melendez, T. A. F.; Mocelin, A.; Zilles, R.; Pinho, J. T. Geração Distribuída com Armazenamento Conectada à Rede Elétrica. In VII Congresso Brasileiro de Energia Solar. VII CBENS, Gramado, 2018, p. 1-8.

103. Junior, M. F. H.; Pinto, R. G. D.; Azevedo, J. T. O. Perspectivas dos sistemas de armazenamento de energia no Brasil. In VII Congresso Brasileiro de Energia Solar. VII CBENS, Gramado, 2018, 1-13.

104. Lopomo, M. R.; Madruga, K. C. R. Tecnologias e políticas orientadas para o armazenamento de energia elétrica no Brasil. In VII Congresso Brasileiro de Energia Solar. VII CBENS, Gramado, 2018, 1-19.

105. Matias, J. A. C.; Betini, R. C. Viabilidade técnica e econômica da utilização de sistemas fotovoltaicos com armazenamento de energia em baterias. In VII Congresso Brasileiro de Energia Solar. VII CBENS, Gramado, 2018, 1-13.

106. Cousins, T. Using time of use (TOU) tariffs in industrial, commercial and residential applications effectively. TLC Engineering Solutions. Available online: https://citeseerx.ist.psu.edu/viewdoc/download?doi=10.1.1.535.7500\&rep=rep1\&type=pdf2009, (accessed on 14 October 2019).

107. Zhang, H.; Zhao, F.; Fang, K.; Sutherland, J.W.; Energy-conscious flow shop scheduling under time-of-use electricity tariffs. CIRP Ann., 2014, 63, 37-40. [CrossRef]

108. P\&S Market Research, Energy Storage Market to Reach $\$ 26,137$ Million by 2022, Available online: https://globenewswire.com/newsrelease/2017/07/07/1041306/0/en/Energy-Storage-Market-to-Reach-26-137-Million-by-2022-P-S-Market-Research.html, (accessed on 17 March 2020).

109. Global energy storage market to hit 8.8 GW by 2025, Available online: https://www.utilitydive.com/news/global-energy-storage-market-to-hit-88-gw-by-2025-ihs-markit-says/448606/, (accessed on 18 March 2020).

110. Supercharged: Challenges and opportunities in global battery storage markets, Available online: https://www2.deloitte.com/us/en/pages/energy-and-resources/articles/global-energy-storage-renewable-energy-storage.html, (accessed on 19 March 2020).

111. After Failing in EVs, Coda Energy Pursues No-Money-Down Building Storage, Available online: https://www.greentechmedia.com/articles/read/coda-energy-joins-the-no-money-down-building-energy-storage-fray, (accessed on 19 March 2020).

112. AES Energy Storage Targets \$30B Peak Power Substitution Market, Available online: http://www.greentechmedia.com/articles/read/aes-energy-storage-targets-30-billion-peak-power-substitution-market, (accessed on 20 March 2020). 
113. Electric Utility Transmission and Distribution Upgrade Deferral Benefits from Modular Electricity Storage, Available online: https://prod-ng.sandia.gov/techlib-noauth/access-control.cgi/2009/094070.pdf, (accessed on 20 March 2020).

114. Stem Well Positioned in On-Site Energy Storage Market, Available online: http://www.forbes.com/sites/peterdetwiler/2015/01/29/stem-well-positioned-in-on-site-energy-storage-market, (accessed on 21 March 2020).

115. The Economics of Battery Energy Storage: How multi-use, customer-sited batteries deliver the most services and value to customers and the grid, Available online: https://rmi.org/insight/economics-battery-energy-storage/, (accessed on 22 March 2020).

116. Gouvêa, A. R. Uma Visão Estratégica do Setor de Distribuição de Energia Elétrica Frente aos Desafios da Expansão de Recursos Energéticos Distribuídos no Brasil. Master's Thesis, Federal University of Rio de Janeiro, Rio de Janeiro, 2019.

117. Jenkins, J. D.; Pérez-Arriaga, I. J. Improved regulatory Approaches for the remuneration of electricity distribution Utilities with high penetrations of distributed energy resources. Ener, Jour., 2017, 38, pp. 63-91. [CrossRef]

118. Castro, N.; Alves, J.; Dantas, G.; Ferreira, D. Estado da arte da difusão de recursos energéticos distribuídos em quatro esta dos norte-americanos. Texto de discussão do setor elétrico, 72, 2017.

119. Bajay, S.; Jannuzzi, G. M.; Heideier, R. B.; Vilela, I. R.; Paccola, J. A.; Gomes, R. Geração distribuída e eficiência energética: reflexões para o setor elétrico de hoje e do futuro (International Energy Initiative, 2018).

120. Barros, L. V. Avaliação de Modelos de Negócio para Energia Solar Fotovoltaica no Mercado de Distribuição Brasileiro. Master's Thesis, University of São Paulo, São Paulo, 2014.

121. ANEEL. National Electric Energy Agency. Normative Resolution 482. 2012. Available online: http://www2.aneel.gov.br/cedoc/bren2012482.pdf, (accessed on 30 November 2020).

122. ANEEL. National Electric Energy Agency Distribution Procedures (PRODIST) module 3, Available online: https://www.aneel.gov.br/documents/656827/14866914/PRODIST-M\%C3\%B3dulo3 Revis\%C3\%A3o7/ebfa9546-09c2-4fe5a5a2-ac8430cbca99, (accessed on 30 November 2020).

123. ANEEL. National Electric Energy Agency. Net compensation. Available online: https://www.aneel.gov.br/documents/656877/14913578/Caderno+tematico+Micro+e+Minigera\%C3\%A7\%C3\%A3o+Distribuida+-+2+edicao/716e8bb2-83b848e9-b4c8-a66d7f655161?version=1.3, (accessed on 30 November 2020).

124. ANEEL. National Electric Energy Agency Technical note 0056/2017 - SRD/ANEEL. Available online: https://www.aneel.gov.br/documents/656827/15234696/Nota+T\%C3\%A9cnica 0056 PROJE\%C3\%87\%C3\%95ES+GD+2017/, (accessed on 30 November 2020).

125. Empresa de Pesquisa Energética. Energy Expansion Plan. Available online: https://www.epe.gov.br/pt/publicacoes-dados-abertos/publicacoes/Plano-Decenal-de-Expansao-de-Energia-2026/, (accessed on 30 November 2020).

126. ANEEL. National Electric Energy Agency. Regulatory Activity 106. Available online: https://www.aneel.gov.br/documents/660863/18941908/Anexo+II+-+Formul\%C3\%A1rios.pdf/41b3a64e-29bb-ed43-1aad-710665ef62c2, (accessed on 30 November 2020). 